\title{
Consistent trade-offs in ecosystem services between land covers with different production intensities
}

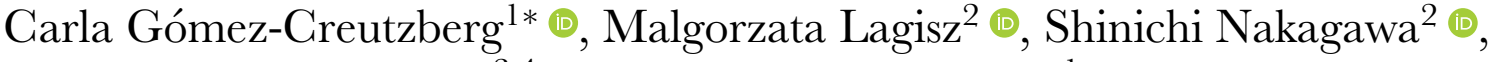 \\ Eckehard G. Brockerhoff ${ }^{3,4} \oplus^{\circ}$ and Jason M. Tylianakis ${ }^{1 *}$ \\ ${ }^{1}$ Centre for Integrative Ecology, University of Canterbury, Christchurch, 8140, New Zealand \\ ${ }^{2}$ Evolution $\&$ Ecology Research Centre, School of Biological, Earth and Environmental Sciences, University of New South Wales, Sydney, NSW, \\ 2052, Australia \\ ${ }^{3}$ Scion (New Zealand Forest Research Institute), Christchurch, 8440, New Zealand \\ ${ }^{4}$ Swiss Federal Research Institute WSL, Zürcherstrasse 111, Birmensdorf, CH-8903, Switzerland
}

\begin{abstract}
Sustaining multiple ecosystem services across a landscape requires an understanding of how consistently services are shaped by different categories of land uses. Yet, this understanding is generally constrained by the availability of fineresolution data for multiple services across large areas and the spatial variability of land-use effects on services. We systematically surveyed published literature for New Zealand (1970-2015) to quantify the supply of 17 non-production services across 25 land covers (as a proxy for land use). We found a consistent trade-off in the services supplied by anthropogenic land covers with a high production intensity (e.g. cropping) versus those with extensive or no production. By contrast, forest cover was not associated with any distinct patterns of service supply. By drawing on existing research findings, we reveal complementarity and redundancy (potentially influencing resilience) in service supply from different land covers. This will guide practitioners in shaping land systems that sustainably support human well-being.
\end{abstract}

Key words: land-use planning, environmental management, ecosystem service bundles, quantitative review, network meta-analysis

\section{CONTENTS}

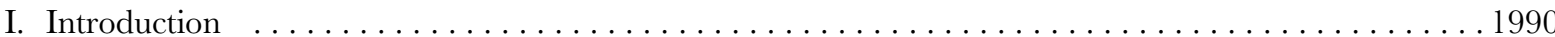

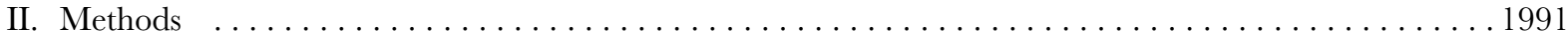

(1) Data collection, aggregation and calculation of effect sizes $\ldots \ldots \ldots \ldots \ldots \ldots \ldots \ldots \ldots$

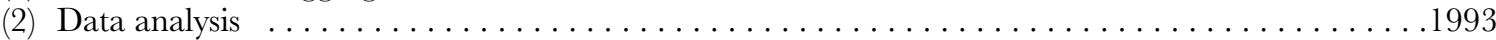

III. Results . . . . . . . . . . . . . . . . . . . . . . . . . . . . . . . . . . . . . . . . . . . . . . 1994

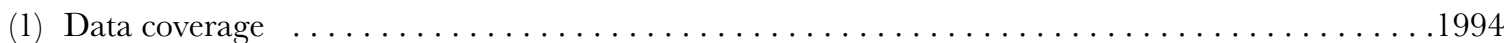

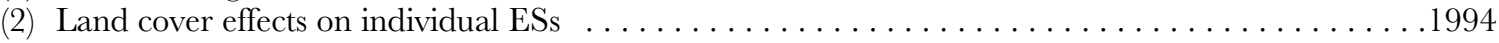

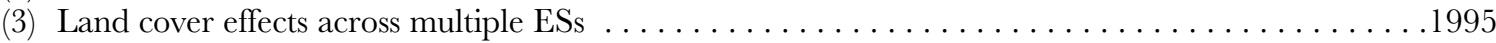

(a) Differences among ESs based on the land covers that supply them . . . . . . . . . . . . . . . . . . . 1995

(b) Differences among land covers in their supply of services . . . . . . . . . . . . . . . . . . . . . . 1995

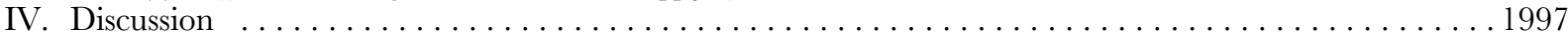

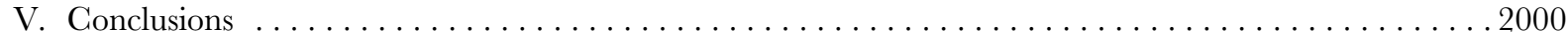

VI. Acknowledgements and author contributions $\ldots \ldots \ldots \ldots \ldots \ldots \ldots \ldots$

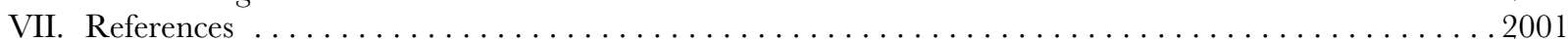

VIII. Supporting information $\ldots \ldots \ldots \ldots \ldots \ldots \ldots \ldots \ldots$

*Authors for correspondence (Tel.: +64 21 2979902; E-mail: cgomezcre@gmail.com); (Tel.: +64 3 3695379; E-mail: jason. tylianakis@canterbury.ac.nz) 


\section{INTRODUGTION}

Human transformation of the Earth's surface through landuse activities has reached an unprecedented magnitude, and constitutes a major driver of global environmental change (Turner, Lambin \& Reenberg, 2008; Steffen et al., 2015). Humans rely on resources appropriated through land use, however most of these practices affect the Earth's ecosystems in ways that undermine human well-being (Foley et al., 2005). Continued population growth and increased per capita consumption of resources (Godfray et al., 2010) make it critical to find ways to reconcile production and sustainability in land systems.

Ecosystem services (ESs) offer a framework for addressing these complex issues by explicitly accounting for the benefits that ecosystems bring to society. Central to this framework is the idea that human well-being is underpinned by a diverse constellation of ESs (MEA, 2005). Most of these ESs are not accounted for in conventional land-use planning and management decisions which, instead, tend to focus on the production of a single ES (e.g. provision of food or timber) (Robertson \& Swinton, 2005; Rodríguez et al., 2006). By highlighting the importance of multiple over individual services, the ESs framework encourages decision makers to prioritize long-term well-being over immediate economic reward (Costanza et al., 2014; Guerry et al., 2015).

As an additional layer, the ESs framework also links resilience in the delivery of ESs to resilience in human societies and the social-ecological systems in which societies participate (Sarkki et al., 2017). Resilience in ES supply is supported by a combination of redundancy in the ecosystems (and their components, e.g. species) that supply the ESs and diversity in their responses to disturbances (Biggs et al., 2012). Similar, but slightly differentiated, ecosystems and components within them are therefore necessary for resilient ES supply, and the spatial arrangement of these ecosystems may provide additional resilience through spatial averaging of service supply and dispersal of functionally important species (Loreau, Mouquet \& Gonzalez, 2003).

Developing strategies that optimize ESs across different land uses, enhance multiple ESs within a single type of land use (Lambin \& Meyfroidt, 2011), or ensure the resilient supply of ESs, relies on understanding the occurrence and interactions among different ESs and their responses to management interventions. To this end, important efforts have been made to map and quantify ES supply [see Crossman et al. (2013), de Groot et al. (2012) and Martínez-Harms \& Balvanera (2012) for reviews] and, more specifically, to assess how different ESs are enhanced synergistically or traded off against each other (Nelson et al., 2009; Bateman et al., 2013).

More recently, research on ES trade-offs and synergies has come together under the concept of ES bundles: groups of ESs that repeatedly appear together in space and/or time (Raudsepp-Hearne, Peterson \& Bennett, 2010; Saidi \& Spray, 2018). Since ESs flow from the ecosystems that generate them to the human beneficiaries that enjoy them, ES bundles can be examined in terms of ES supply by ecosystems (Queiroz et al., 2015) and ES demand by human beneficiaries (Ament et al., 2017). In either case, ES bundles can be used subsequently to identify common processes or external factors driving different ESs (Mouchet et al., 2014).

Research on ES bundles has faced criticism on the grounds that spatial correlations or correlations between indicators of ESs are at times readily presented as evidence for interactions between services (Vallet et al., 2018; Obiang Ndong, Therond \& Cousin, 2020). This reflects a broader need for introducing a more mechanistic approach that can identify the drivers underpinning the relationships observed between ESs (Dade et al., 2019). We do not attempt to duplicate those arguments here, but rather address the difficulties in obtaining cross-site comparisons and generalizations of bundles and their drivers. A systematic review of 51 studies on ES bundles linked those difficulties to the existence of multiple approaches to bundling ESs (Saidi \& Spray, 2018). However, even when the same methods, data sets and groups of ESs were used to identify ES bundles and their relation to social-ecological variables in two regions, the results were highly inconsistent between regions (Spake et al., 2017) and, therefore, not generalizable to other locations. This inconsistency may result from the choice of ES indicators, socioecological variables and spatial units of analysis (Spake et al., 2017). Often, studies that examine ES bundles use administrative units (e.g. municipalities) as the scale at which ESs are quantified (Saidi \& Spray, 2018). However, administrative units can mask ES associations because they: $(i)$ are variable in size (within the same hierarchical level); (ii) occur at scales that are too coarse to capture the fine-scale processes linked to some ESs; (iii) encompass heterogeneous sets of land covers/land uses; and (iv) have boundaries that may cut across ecologically relevant units (Spake et al., 2017). Therefore, identifying consistent rules regarding ES bundles and their drivers requires tailored analyses (Dade et al., 2019) that focus on finer scales (Cord et al., 2017), such as ESs measured in individual plots within land cover types (Spake et al., 2017).

Here we test directly whether there are any general rules for the effect of land use on ES bundles by assessing the supply of multiple ESs across land covers (as a proxy for land use) at a national scale. We systematically surveyed the published literature for New Zealand (1970-2015) to collate studies with quantitative evidence of how different land covers compare against each other in processes relating to the supply of one or more ESs. For each study, we calculated standardized pairwise comparisons (expressed as log response ratios) of land covers in their supply of individual services. We used these ratios to conduct network meta-analyses for individual services and obtained, for each service, quantitative estimates of service supply from individual land covers.

With this comprehensive evidence base, we first discuss land cover effects on individual ESs and then examine associations between ESs to delineate any potential synergies and trade-offs arising from services that are best supplied by similar or different land covers. Similarly, we also examine associations between land covers based on the different ESs they supply. Previous research has shown that attributes of single 
land-cover types can drive the value of multiple ESs (Sutherland, Gergel \& Bennett, 2016) and trade-offs and synergies among ESs (Felipe-Lucia et al., 2018). We therefore analyse patterns of covariance in the response of multiple ESs to land-cover differences in order to detect: $(i)$ any land covers that may be operating as 'generalists' (i.e. supplying many ESs) or 'specialists' (i.e. supplying just a few ESs); and (ii) groups of land covers that supply similar profiles of ESs (i.e. ES bundles sensu Raudsepp-Hearne et al., 2010). The latter includes services that are typically traded off against each other.

Duarte et al. (2018) present evidence that landscape composition metrics (e.g. percentage of natural areas and of non-crop areas) affect some ESs (water quality, pest regulation, pollination and disease mitigation); however, their analysis did not identify specific attributes of natural or non-crop areas that could shape ES supply. Therefore, as a second step we test whether there are generalities regarding how categories of land cover influence ES bundles (i.e. sets of ESs supplied consistently across more than one land cover) by testing for systematic differences between forested and nonforested habitats and between exotic-species-dominated production and native non-production land covers (note that we use the term 'production' to refer to economic activity rather than primary production). If they exist, these differences would suggest that production/no production, forest/nonforest cover and native/exotic vegetation are attributes that drive changes in ES supply across multiple land covers. By extending the perspectives of Duarte et al. (2018) to include attributes shared by multiple land covers, our results can potentially inform management decisions at broader scales and allow generalities across regions and land covers. We conclude with an example of how our findings can be used to examine the effects of land cover trajectories or contrasting management decisions on landscape-scale ES trade-offs.

\section{METHODS}

Unlike existing reviews and meta-analyses on ESs (e.g. Howe et al., 2014; Nieto-Romero et al., 2014; Malinga et al., 2015; Lee \& Lautenbach, 2016), our work does not collate existing ES assessments. Rather, we synthesize primary biophysical research that compares land covers in relation to a large variety of measures (which we term 'ES indicators') that indicate the supply of an ES, regardless of whether ES terminology was used. Therefore, the evidence base for our metaanalysis is not confined to the recent wave of studies focusing specifically on ESs, but also encompasses research that, having originated in a different field or during a time before ES terminology was widely used, still contains suitable data for quantifying ES supply across land covers. Our terms and criteria are described below in Section II.1.

Despite the growing literature on ESs (Chaudhary et al., 2015), our understanding of ES bundles, trade-offs and synergies has traditionally been impaired by the lack of, and costliness of obtaining, detailed spatial data on multiple ESs from multiple land uses across landscapes (Andrew et al., 2015). This has led to the widespread approach of using expert or model estimates of ESs per land use or land cover class as input for ES assessments [see Jacobs et al. (2015) for a review; Aldana Domínguez et al. (2019) and Chen, Chi \& Li (2019) provide recent examples]. Here, we propose an alternative approach that makes it possible to use primary data to study land cover and ES relations by capitalizing upon existing research across multiple disciplines.

We use New Zealand as a case study because the high levels of endemic flora and fauna and relatively recent introduction of large-scale intensive agriculture make conservation-production tensions particularly acute, and necessitate conservation strategies that go beyond protected areas (Craig et al., 2000). Since human occupation began, the two main islands (North and South) of the New Zealand archipelago have lost an estimated $71 \%$ of their original indigenous forest cover (Ewers et al., 2006). Although deforestation rates have decreased over recent decades and almost one-third of the country's land area is protected as conservation land, the remaining forest may not be sufficient to prevent species extinction (Ewers et al., 2006). Since 1960 the country has been experiencing accelerated intensification of its agricultural production, which is dominated by beef, sheep and, in the past two decades, dairy (MacLeod \& Moller, 2006; Foote, Joy \& Death, 2015).

Our systematic review was structured according to the Guidelines for Systematic Review in Environmental Management developed by the Collaboration for Environmental Evidence (CEE, 2013). We searched the literature for quantitative comparisons of two or more land covers in the supply of one or more ES within New Zealand. Our ES definitions were adapted from the Millennium Ecosystem Assessment (MEA, 2005), with a total of 32 ESs spanning the provisioning, regulating, cultural and supporting categories (see online Supporting Information, Supplementary Data Set S1). Despite debates on whether the MEA classification of ESs leads to double-counting of some services (Wallace, 2007; Fisher, Turner \& Morling, 2009), we adopted it here because of its wide use and because our main interest was not to render a final valuation of ESs (where double-counting would be an issue), but instead to provide a comprehensive overview of the complete spectrum of direct and indirect benefits from ecosystems. Land uses, formally defined as the purposes to which humans put land into use (Dale et al., 2000), were captured in our research as land covers (Supplementary Data Set S2), since these include units that are not directly used by humans and, consequently, correspond more closely with the actual experimental or sampling units of many of the documents in our search.

\section{(1) Data collection, aggregation and calculation of effect sizes}

Full details of the search and screening process are described in Supplementary Methods S1; here we present a brief 
outline. We searched the Scopus database for titles, abstracts and key words with at least one match in each of the three components that structured our search: (i) 'New Zealand', (ii) land-cover and land-use terms, and (iii) ES terms (see Supplementary Methods S2 for the full search phrase). Land cover terms included all possible variations of 'land use' and 'land cover' as well as the names of specific land use and land cover types (both generic and specific to New Zealand). The ESs component drew upon the names of each service (and possible variations of these) but also included vocabulary describing processes and conditions that could reflect their supply at the site scale akin to individual land cover units. The search was finalized in January 2015, and was constrained to include documents published from 1970 onward, to be comparable with current land use regimes in New Zealand (MacLeod \& Moller, 2006).

Our key word search yielded 9741 references. An initial automated screening process reduced these to 4373 publications by removing references that only mentioned a single type of land cover or land use in their title, abstract or key words. We excluded these studies because measures of ES supply from single land covers could not be standardized in a way that would make them comparable across studies and compatible with the standardized land cover comparisons of ES supply that informed the rest of our meta-analysis.

Publications with two or more land cover terms were scanned using Abstrackr, an interactive machine-learning system for semi-automated abstract screening, often used in medical meta-analyses (Wallace et al., 2012). By learning from the abstracts or words that a user identifies as relevant during the screening process, Abstrackr can predict the likely relevance of unscreened abstracts and effectively assist in the exclusion of irrelevant ones (see Supplementary Methods S1 for further details).

Abstract screening yielded 914 relevant papers, which were passed on to a team of four reviewers for full-text assessment and data extraction. Studies that did not have replicated observations (as defined in Supplementary Methods S1) for any land covers were discarded, whereas studies that contained replication on some, but not all, of the land covers were retained, with only data on the replicated land covers extracted. Although we only included terrestrial land covers, ESs supplied by land but linked to a water body were included in our analysis. Full details of how the full-text selection criteria were applied can be found in Supplementary Methods S3. In total, we extracted data from 133 studies that met all inclusion criteria (see Supplementary Data Set S3 for bibliographic details of each study).

Information on the land covers, quantitative measures of ES supply, experimental design and bibliographic details for each study was collated in a database. To allow for comparability across studies, individual land covers described in each study were matched to the nearest category in New Zealand's Land Cover Database (LCDB; Thompson, Grüner \& Gapare, 2003). This classification system includes forest, shrubland and grassland areas of either predominantly native or exotic vegetation, as well as cropland and more artificial surfaces such as built-up surfaces and mining areas (Supplementary Data Set S2).

Often, the same quantitative measure of ES supply obtained from a study (indicators; provided in Supplementary Data Set S4) was relevant to more than one ES. This reflects the overlaps that exist between different ESs (e.g. soil structure plays a role in both soil formation and regulation of water timing and flows), and the multiple values that humans can receive from a given ecosystem process. We therefore decided to assign each indicator to as many ESs as it was relevant to, and use this allocation in our main analysis. However, to understand the influence on our results of sharing indicators among ESs, we also conducted the same analysis with each indicator assigned to only one ES. See Supplementary Results S5 for the results of this analysis.

For each indicator-ES combination, we defined the general direction of the relationship by determining whether larger values of the indicator would generally reflect an increase or decrease in ES supply. This was done because the majority of studies in our meta-analysis did not explicitly use ESs terminology. Instead, they measured environmental or ecological variables that could be used as indicators of ES supply, provided a conceptual link could be defined between the indicator (e.g. annual water discharge of a catchment) and the corresponding ES (in this case, provision of fresh water). When we could not readily assign indicators to ESs or determine the direction of the indicator-ES relationship, we consulted experts with specialized knowledge of the field related to each indicator (see Section VI). Although we recognize that the relationship between an indicator and an ES may be non-linear (e.g. pollination services may saturate with large numbers of pollinators; Fründ et al., 2013), in most cases it was not possible to establish a clearly defined non-linear function, so we assumed a linear relationship for all indicators. The indicators we used to quantify ES supply are listed in Supplementary Data Set S4, which also provides an overview of the relations we defined between each indicator and ES.

Unique identifiers allowed us to define individual studies, regardless of whether they were within a publication that included more than one study or across different publications (Supplementary Methods S1). Multiple measures (i.e. pseudoreplicates) from within the same replicate site were aggregated into a single value per replicate (see Supplementary Methods S1 for details). Methods for standardizing measures of variance are presented in Supplementary Methods S4.

We obtained a final database with information on $457 \mathrm{ES}$ indicators among 2943 pairwise comparisons of land covers from 133 studies. A log response ratio was used as the effect measure for comparing pairs of land covers within each study, and was standardized such that larger values always represented greater ES supply in the numerator land cover relative to the denominator one (see Supplementary Methods S1 for this standardization and log response ratio variance calculations).

Studies with more than one indicator of a given ES were aggregated to have the same weight as studies with only a 
single indicator (this was based on either the mean log response ratio across multiple indicators or the single indicator represented in all land covers of a study, see Supplementary Methods S1 for details). Subsequently, the total number of land cover comparisons in our final data set of 133 studies was reduced from 2943 to 920 comparisons for individual ES within single studies (see Supplementary Data Set S5 for an overview of the final data set).

\section{(2) Data analysis}

Data analysis was conducted as a two-stage process: we first examined the supply of each ES by different land covers, and then assessed the relationships among land covers in terms of multiple ESs. For the first stage, we conducted a separate network meta-analysis (Salanti, 2012) for each ES. While conventional meta-analysis compares two treatments at a time (using direct comparisons from each study), a network meta-analysis can compare multiple (i.e. three or more) treatments simultaneously. This is achieved by using both direct evidence (studies comparing pairs of treatments) and indirect evidence derived from linking common treatments across different studies in a network of evidence (Salanti, 2012). For example, if some studies show that land cover A is better than B in supplying an ES, and others provide direct evidence that $\mathrm{B}$ is better than $\mathrm{C}$, then a network meta-analysis allows us to make the indirect inference that A will also be better than C. We therefore used network meta-analysis to compare, for each ES, a wide array of land covers across different studies, even though we did not have data for direct comparisons among all combinations of land covers.

We conducted our network meta-analyses with the $\mathrm{R}$ package Netmeta (Schwarzer et al., 2019), which offers a frequentist approach to calculate point estimates (and their corresponding 95\% confidence intervals) of the effect of the different land covers on the supply of individual ESs. Estimates were expressed as the log response ratio of each land cover relative to a reference land cover: high-producing exotic grassland. We selected this land cover as our reference because it was the only land cover that was represented across all ESs in our data set (and would therefore allow us to compare our results across ESs at a later stage).

In Netmeta, we used a random-effects meta-analytic model to generate estimates and confidence intervals from which we then calculated probability scores $(P$-scores; Rücker \& Schwarzer, 2015) on how different land covers ranked in the supply of each ES. Estimates, confidence intervals and $P$-scores then allowed us to construct, for each ES, a so-called forest plot or blobbogram (sensu Lewis \& Clarke, 2001) to compare different land covers in their ES supply.

Bundles, trade-offs and synergies in land cover effects across the whole suite of ESs were then examined using hierarchical clustering of the network meta-analytic estimates. For this, we constructed a land cover by ES matrix (see Fig. S44, Supplementary Results S3) using the estimated $\log$ response ratios of each land cover (relative to the high-producing exotic grassland reference) in each ES, as determined by the individual network meta-analyses. Missing values in this matrix resulted from sets of land covers for which we had no information on a given ES or could not infer the corresponding ratios indirectly.

For analysis, we selected subsets of this matrix with no gaps and the largest possible number of total cells. This resulted in two data subsets: a matrix of nine ESs by eight land covers and another matrix with nine land covers by eight ESs. The matrix with nine ESs was rotated to have ESs as rows (land covers as columns) and used to compare ESs in terms of the land covers that supply them. This allowed us to identify ES bundles (sets of ESs supplied similarly across multiple land covers), synergies in ES supply, and ESs that would likely be traded off with one another in land-use decisions. The matrix with nine land covers was used to compare land covers (to identify complementarity and redundancy) in the supply of eight ESs. This allowed us to explore how land-cover differences influence ES bundles.

We calculated a dissimilarity matrix from each of these matrices using the daisy function of the cluster package for $\mathrm{R}$ (Maechler et al., 2019) with Euclidean distances. For the rotated matrix with nine ESs, distances were based on ES observations for each land cover, while for the matrix with nine land covers, distances were based on land cover observations for each ES. We applied hierarchical clustering (using the $\mathrm{R}$ hclust function; R Core Team, 2019) to each of the distance matrices and constructed dendrograms on how different land covers or ESs compared against each other. Following Raudsepp-Hearne et al. (2010), we also used these distance matrices to conduct k-means cluster analysis (with the kmeans function in the base package of $\mathrm{R}$; $\mathrm{R}$ Core Team, 2019) to identify groups of land covers and ESs exhibiting similar behaviour. In each case, the number of clusters was determined using a scree plot (see Figs S3 and S4 in Supplementary Methods S5).

Finally, we used our distance matrices with nine land covers to test hypotheses on whether broad categories of land covers explained the trends observed in the corresponding clustering. Specifically, land covers were grouped under two categorical variables, one denoting the presence/ absence of forest cover and another separating production land covers, dominated by exotic vegetation cover, from those with no production activities. Originally, we expected to compare land covers with a native versus exotic vegetation cover separately from production versus no production. However, we omitted the former category because, except for one, all land covers with exotic vegetation were production and all native covers had little or no production (see Table S1, Supplementary Methods S5). We used a permutational multivariate analysis of variance (PERMANOVA) to test whether these variables or their interaction explained between-land-cover differences in the supply of multiple ESs.

PERMANOVA analyses were conducted using the adonis function of the vegan package in $\mathrm{R}$ (Oksanen et al., 2019). Variables are added sequentially in the adonis algorithm. To be conservative, we performed the PERMANOVA twice and 
swapped the order of the variables in the second iteration, so that each variable was tested second, after controlling for any collinearity with the other predictor (i.e. adjusted sums of squares). The betadisper function of the vegan package was used to test the assumption of multivariate homogeneity of group dispersions, and all tests met this assumption. Table S1 presents the land cover categories used in these analyses.

\section{RESULTS}

\section{(1) Data coverage}

From our systematic survey, we identified a total of 133 studies that were relevant to our analysis and matched our selection criteria. Overall, these studies contributed data on 17 different ESs, 25 land cover types and 457 measures (which we term 'ES indicators') on ES supply. All four of the MEA ES categories (supporting, provisioning, regulating, and cultural services; MEA, 2005) were represented within our data set. However, most studies examined supporting and regulating services, with 115 and 110 studies, respectively. Only 44 studies presented data on provisioning services and four on cultural ones. All of the ESs in the supporting category (habitat provision, nutrient cycling, soil formation, water cycling and primary production) are represented in our database. Only four land cover comparisons had more than 20 studies (high-producing exotic grassland versus exotic forest, indigenous forest versus high-producing exotic grassland, short-rotation cropland versus highproducing exotic grassland and exotic forest versus indigenous forest); whereas the remaining land cover pairs were represented by 10 or fewer studies each. Further details on the number of studies per land cover comparison and per combination of ES and land cover are available in Supplementary Results S1.

\section{(2) Land cover effects on individual ESs}

There were consistent trends in the supply of multiple services by specific land cover types, but also great variability in the supply of some services. An overview of the evidence base (number of studies, types of ES indicators and network of land cover comparisons) and the outcomes of the individual network meta-analyses for each of the $17 \mathrm{ESs}$ in our database is presented in Supplementary Results S2. In this supplement, we use forest plots (sensu Lewis \& Clarke, 2001; see Fig. S8 in Supplementary Results S2 for an example) to show the main results of the meta-analysis, i.e. how different land covers compare against each other in their supply of individual ESs. Specifically, the values in these plots are given as log response ratios which express the overall estimates of service supply by individual land covers relative to a reference land cover (high-producing exotic grassland).

For several ESs, the positive log response ratio estimate and narrow confidence intervals in the forest plots (see Figs S8, S17, S19, S38, Supplementary Results S2) reveal that land covers with native vegetation cover (broadleaved indigenous hardwoods, indigenous forest, tall tussock grassland and, in many cases, mānuka/kānuka) tended to rank higher in ES supply than the more intensive high-value production land covers (particularly short-rotation cropland and high-producing exotic grassland). Regulation of water timing and flows, water purification, freshwater provision and disease mitigation conformed to this general pattern. In these services, low-producing grasslands (which comprise a mix of exotic and native vegetation) and exotic forests also perform relatively well and, when present, always rank within the top half of all land covers.

For habitat provision (Fig. S13) the difference between land covers with native vegetation and production systems was less important than the presence of forest vegetation cover. For this service, most land covers with forest vegetation (exotic forest, broadleaved indigenous hardwoods and indigenous forest) ranked higher in their estimates of ES supply than those with open covers (short-rotation cropland, tussock, low- and highproducing grasslands) or deciduous hardwoods. Meanwhile, primary production (Fig. S23) tended to be highest under production systems (e.g. croplands, exotic forest, and high-producing exotic grassland) and lower in land covers with low or no production (e.g. low-producing and tall tussock grasslands, indigenous forest), rather than differing between forested and open covers. However, these trends were not statistically significant due to the wide and overlapping confidence intervals.

Importantly, these results indicate that no single land cover supplies all ESs at a maximal level. Indigenous forests ranked high in the supply of many ESs [particularly habitat provision (Fig. S13), freshwater provision (Fig. S17), disease mitigation (Fig. S38) and global climate regulation (Fig. S21)]. However, in some ESs they were outperformed by other land covers such as tall tussock grasslands (which were well suited to water purification; Fig. S19) and advanced successional forest (broadleaved indigenous hardwoods, which ranked high in regulation of water timing and flows, nutrient cycling and habitat provision; Figs. S8, S11 and S13). Therefore, multiple land covers will be required within the landscape to ensure the supply of multiple ESs.

The forest plots for primary production (Fig. S23), erosion control (Fig. S27), pest regulation (Fig. S30), waste treatment (Fig. S32), capture fisheries (Fig. S34), ethical \& spiritual values (Fig. S36), pollination (Fig. S41) and regional \& local climate regulation (Fig. S43) all present wide, overlapping confidence intervals for all or most of their estimates. This suggests statistically non-significant differences in the supply of these services among land covers. For some services, this could be due to small evidence bases, either in terms of few studies or few comparisons for specific land cover pairs within the network of land cover comparisons that inform the meta-analysis. However, in the case of erosion control, where the evidence base is formed by 22 studies (see Supplementary Results S2), overlapping confidence intervals in the land covers with the greatest number of comparisons (which would therefore be expected to have lower variance) still expressed high variability in ES supply, suggesting that other factors besides land cover (e.g. slope, soil type) likely account for the differences in erosion control across the sites in all 22 studies. 


\section{(3) Land cover effects across multiple ESs}

We explored how the above trends in the supply of individual services translate into bundles, synergies and trade-offs among ESs. For this, we conducted multivariate analyses to simultaneously explore differences in the supply of multiple services across land covers (see Section II.2 and Fig. S44 in Supplementary Results S3). These analyses allowed us to examine whether groups of ESs responded similarly to differences in land cover and, conversely, whether groups of land covers played a similar role in the supply of multiple ESs.

(a) Differences among ESs based on the land covers that supply them

For this analysis we used a matrix of eight land covers by nine ESs to identify clusters of ESs based on how they are supplied by different land covers. We identified a total of five clusters, three of which were formed by only one ES while the remaining two had two and four ESs each (Fig. 1). This suggests that more than half of the nine ESs in this analysis are supplied in a distinct way by different land covers, and reinforces the notion that multiple land covers are required to supply a range of ESs. Moreover, the separation of services into clusters of one or two also suggests that their supply is tradedoff across land covers. This trade-off is acute for waterrelated services; most of which tend to occupy distinct spaces within the dendrogram, with water cycling standing apart from all other ESs, water purification and freshwater provision in a separate cluster, and regulation of water timing and flows in a single branch close to global climate regulation and nutrient cycling (Fig. 1). Freshwater provision and water purification form a cluster because the water-quality aspect of their supply was assessed with the same indicators for both services (Supplementary Data Set S4) and, in both cases, greater service supply came from land covers contributing to enhanced water quality (such as tall tussock grassland and indigenous forest; Figs S17 and S19).

In contrast to water-related ESs, those more closely linked to the soil system (nutrient cycling and soil formation) are found closer to each other in Fig. 1, and appear to be delivered similarly across land covers (Figs S11 and S15). In our analysis, global climate regulation falls under this broad group of services and is closely linked to nutrient cycling (Fig. 1).

(b) Differences among land covers in their supply of services

Our analysis of how land covers compared against each other in their supply of ESs was based on a matrix of nine land covers by eight ESs. We found a gradient of land covers that separates those with lower production from high-value production systems (Fig. 2). Land covers with high production value and dominated by exotic vegetation cover (croplands, high-producing exotic grassland, exotic and harvested forests) occupied separate clusters from those with low or no production and primarily native components in their vegetation cover (tall tussock and low-producing grassland, mānuka and/or kānuka and indigenous forest). Likewise, with the exception of low-producing grassland, land covers with forest vegetation cover occupied separate clusters from those with a more open vegetation cover.

The clusters with single land covers in Fig. 2 appear to specialize in supplying high levels of only one to three of the nine ESs used in the analysis. Tall tussock grassland supplies high

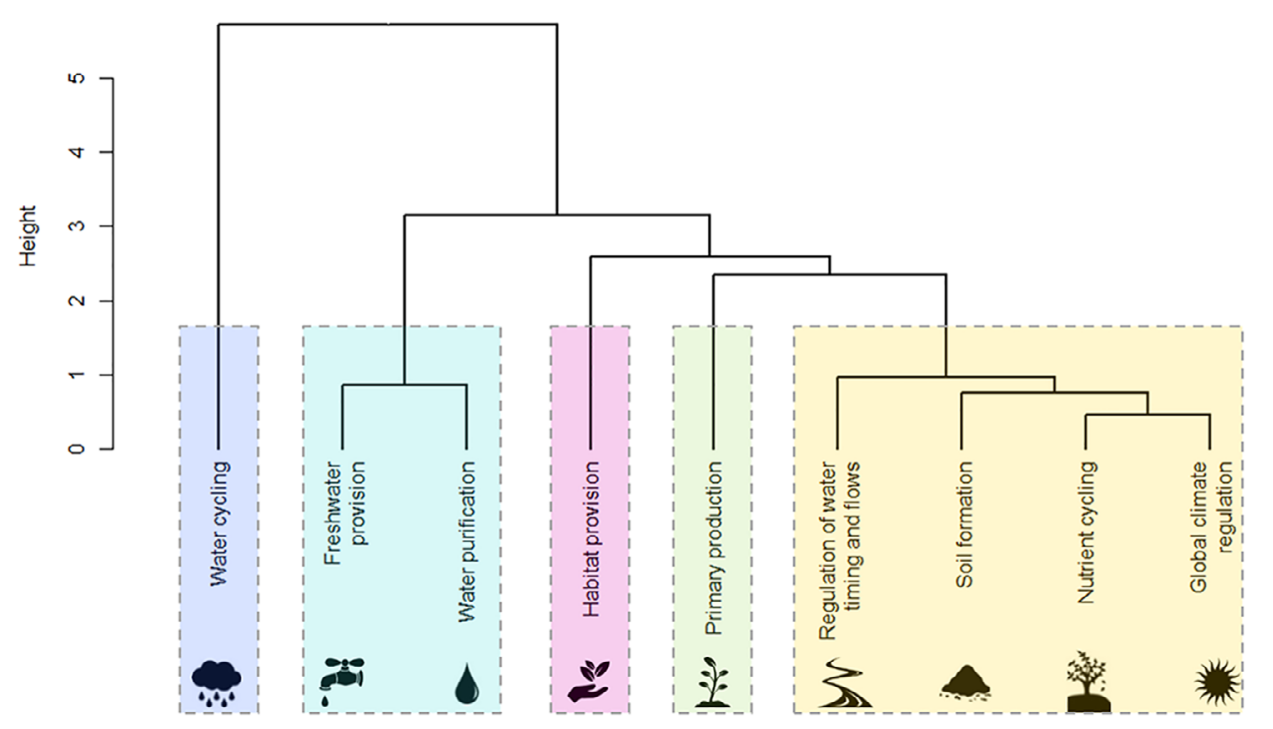

Fig 1. Hierarchical clustering of ecosystem services (ESs). Services within the same box form a cluster (as determined by k-means cluster analysis) and are therefore supplied similarly across eight land covers (low-producing grassland, tall tussock grassland, highproducing exotic grassland, short-rotation cropland, indigenous forest, exotic forest, harvested forest and orchard, vineyard \& other perennial crops). A greater separation between the branching points for clusters along the height axis indicates greater dissimilarity among clusters in the extent to which they are supplied by the eight land covers included in this analysis. 


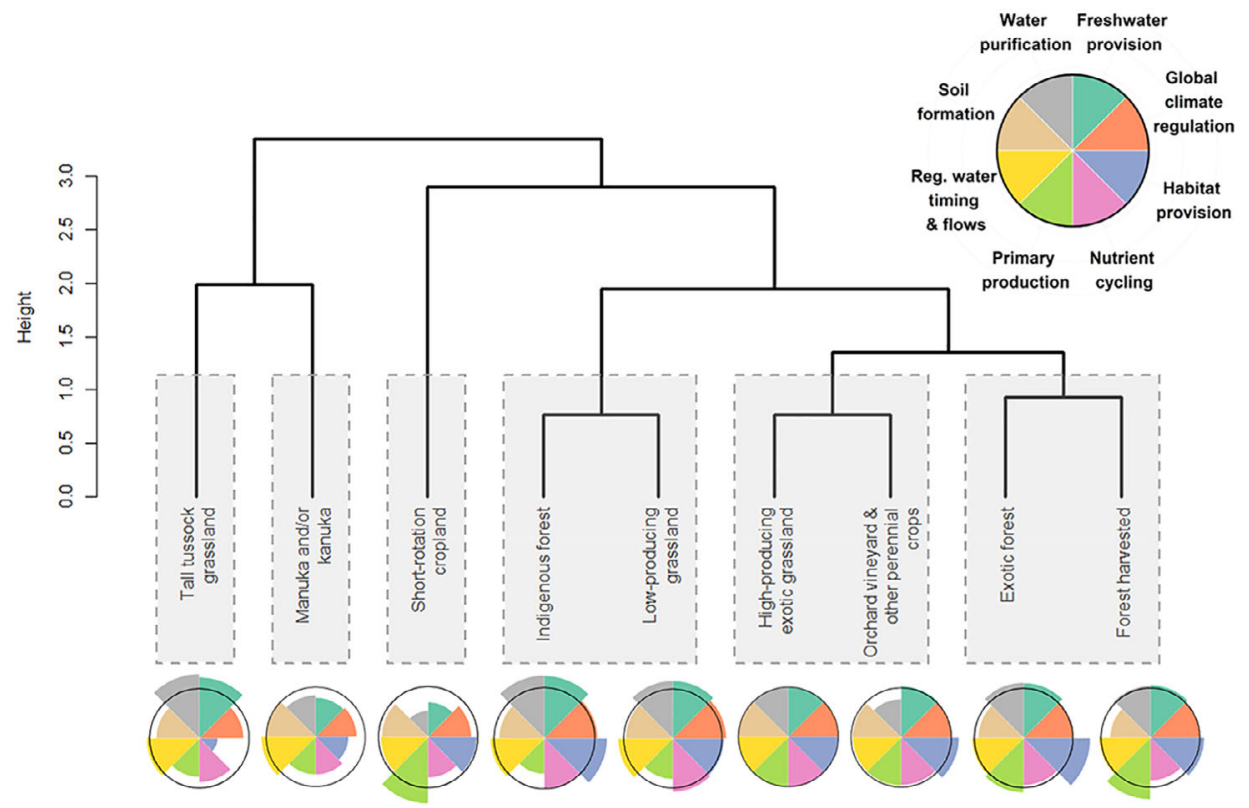

Fig 2. Hierarchical clustering of land covers. Boxes enclose land covers that exhibit a greater similarity in their supply of eight ecosystem services (ESs) (habitat provision, primary production, freshwater provision, soil formation, nutrient cycling, water purification, global climate regulation and regulation of water timing and flows). By contrast, land covers that merge at a greater height have a greater dissimilarity in their service supply. The flower diagrams at the bottom illustrate how each land cover supplies each of the eight ESs, with longer petals indicating a greater supply of an ES. For comparison, the black ring around each flower diagram marks the supply from high-producing exotic grassland, the land cover used as a reference in our meta-analysis.

levels of water purification and freshwater provision, while mānuka and/or kānuka (a successional land cover) is noted for soil formation and regulation of water timing and flows; short-rotation cropland ranks high in supplying primary production. By contrast, the three clusters with pairs of land covers in Fig. 2 exhibit a more uniform supply of the different ESs. Nevertheless, each of these three clusters also appears to supply a distinct ES bundle. The cluster formed by exotic and harvested forests supplies a bundle with high primary production and habitat provision while the cluster formed by indigenous forest and low-producing grassland supplies a bundle specializing in purifying, providing and regulating the flow of water. Lastly, the cluster formed by highproducing exotic grassland and orchard, vineyard \& other perennial crops appears to supply even (yet not necessarily high) levels of all ESs.

Greater differences in ES supply can be inferred from the differences in the height at which clusters separate from each other (Fig. 2). Consequently, in Fig. 2, the clusters with two production land covers (harvested and exotic forest plus high-producing exotic grassland and orchard, vineyard \& other perennial crops) are similar in their supply of ESs but differ from the cluster with indigenous forest and lowproducing grassland. In turn, these three clusters with pairs of land covers are more similar to each other (indicated by the lower branch point) than they are to the clusters with single land covers. The clusters with pairs of land covers are also closer to the short-rotation cropland than to tall tussock grassland and mānuka and/or kānuka, which are more similar to each other than they are to the rest of the land covers.

The trade-off in service supply between production and non-production land covers was statistically significant [PERMANOVA, Pseudo $F_{1,6}=3.064$, partial $R^{2}=0.312$, $P=0.015$ (partial effect of production, when entered before forest cover in a model where variance is attributed sequentially) and Pseudo $F_{1,6}=3.119$, partial $R^{2}=0.318$, $P=0.055$ (partial effect of production, when entered after forest cover in a model where variance is attributed sequentially); detailed results in Supplementary Results S4]. The assumption of homogeneous dispersion between both groups was met $\left(F_{1,8}=0.718, P>0.05\right)$, suggesting that neither supplies a greater range of ESs among its different land covers. Conversely, the separation between forested and nonforested land covers did not significantly explain the distribution of land covers in ES space [Pseudo $F_{1,6}=0.536$, partial $R^{2}=0.055, P>0.05$ (partial effect of forest cover, when entered before production in a model where variance is attributed sequentially) and Pseudo $F_{1,6}=0.592$, partial $R^{2}=0.060, P>0.05$ (partial effect of forest cover, when entered after production in a model where variance is attributed sequentially); see also Supplementary Results S4] nor did the interaction between forested/non-forested and production/non-production [Pseudo $F_{1,6}=1.159$, partial $R^{2}=0.118, P>0.05$ (both when production is entered before forest cover and when forest cover is entered before production in models where variance is attributed sequentially); Supplementary Results S4]. 
Case 1

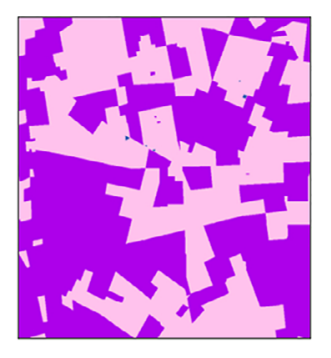

'ES supply space'

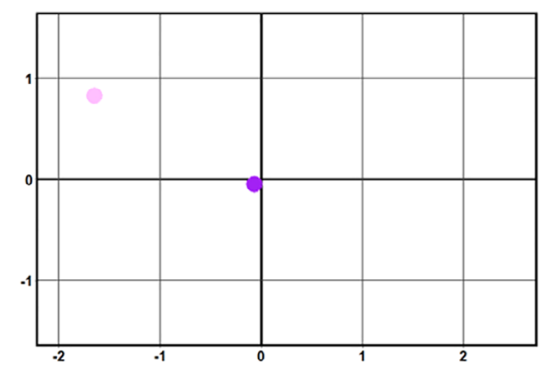

Case 2
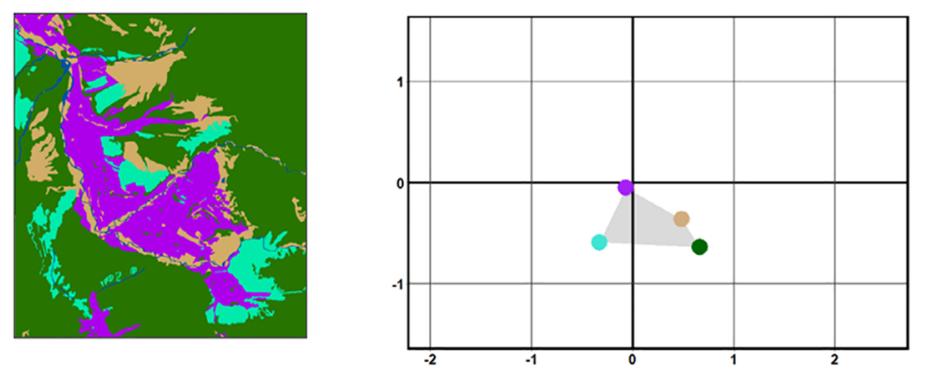

Land covers

Broadleaved indigenous hardwoods

Exotic forest

Forest harvested

High producing exotic grassland

Indigenous forest

Low producing grassland

Manuka and/or kanuka

Orchard, vineyard \& other perennial crops

Short - rotation cropland

Tall tussock grassland
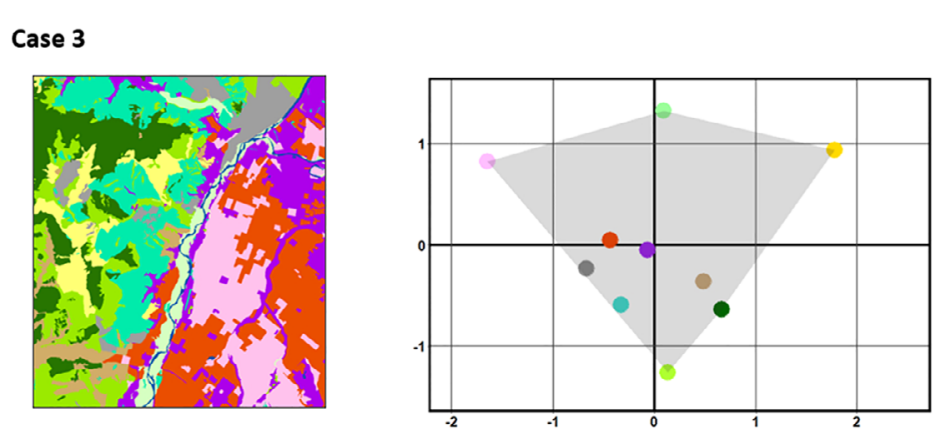

Fig 3. Example visualizations for exploring land cover trade-offs in the supply of multiple ecosystem services (ESs) from entire landscapes. Quantitative measures of ES supply by different land uses or land covers (such as those obtained from our metaanalysis) can be used to generate ordinations that 'map' land covers or land uses into the multidimensional space of ES supply (ordination graphs). Distribution of land covers within that space can assist with identification of redundancies in ES supply (among land covers/uses that map close together) and trade-offs among land covers/uses that supply contrasting sets of ESs and, consequently, occupy opposite extremes of the ordination space. Furthermore, the hypervolume enclosed by the total set of land covers/uses from a given landscape expresses the diversity of ESs provided by that landscape. As an example, our data can be used to compare multi-service provision for: a landscape with few, undifferentiated production land covers (Case 1); a landscape with a combination of some production and non-production land covers (Case 2) and a landscape with a broad range of production and non-production land covers that supply a diverse range of services (Case 3).

\section{DISGUSSION}

We have synthesized over 40 years of quantitative primary evidence on the ESs supplied by different land cover types at a national scale, and used this to identify bundles and trade-offs among ESs, as well as general land cover characteristics driving these associations. Our method for using existing data to assess bundles, trade-offs and synergies in ES supply across land covers can be used to facilitate the comparison of entire landscapes, for example, by projecting land covers or land uses into multidimensional ES-supply space (Fig. 3). This mapping could reveal two key characteristics for land-use planning: ( $\imath$ land covers/uses that cluster together (see also Fig. 2), and thus exhibit redundancy (and potentially resilience) in ES supply, or (ii) land covers/uses that occur at opposite extremes of ES-supply space, and are therefore likely to exhibit complementary roles in their service supply (as ESs are traded off between them). To facilitate the latter, we identified general characteristics that separate groups of land covers in ES-supply space. 
We found strong evidence that high-value production land covers supplied a different set of non-market services than all the land covers with low or no production and native elements in their vegetation cover. Together, land covers with low or no production outperformed the production ones in supplying several supporting and regulating ESs (e.g. freshwater provision, disease mitigation and regulation of water timing and flows). By contrast, most production land covers specialized in supplying primary production. The trade-off between water cycling and regulation of water timing and flows (Fig. 1) probably occurred because land covers that allow for increased runoff and present low water retention (such as harvested forests, croplands and built-up areas) deliver more of the water cycling service than land covers that promote soil water storage and, consequently, perform better in regulating water timing and flows (e.g. broadleaved indigenous hardwoods, indigenous forests and low-producing grasslands).

In contrast to the dissimilarity between production versus non-production/native land covers, forest cover (either native or exotic) was not associated with significant differences in the suite of services supplied. Instead, we observed a close affinity between land covers with contrasting forest covers (e.g. between low-producing grassland and indigenous forest and between exotic forests and high-producing exotic grasslands) in their supply of several ESs including water purification and regulation of water and timing of flows. Only for habitat provision did we observe that land covers with a forest cover (indigenous forest and exotic forest, both harvested and unharvested) performed better than those without a forest cover in service supply.

Beyond identifying trade-offs among specific land covers, the total hyper-volume occupied by all land covers/uses in the multidimensional ES-supply space (ordination plots in Fig. 3) can indicate the diversity of ESs supplied by all land covers/uses within a given landscape (analogous to interpretations of species in trait space; Laliberte \& Legendre, 2010), which could be used in comparisons of existing landscapes or future scenarios.

For example, Case 3 in Fig. 3 has the greatest diversity of land covers and thus occupies the greatest hyper-volume in multidimensional ES-supply space (signifying diverse ES supply). However, there are few land covers at the edge of this volume, such that the full array of services has low redundancy compared with Case 2, where land covers cluster around one location in ES-supply space. Given that resilience in ES supply hinges on the redundancy of the ecosystems supplying those services (Biggs et al., 2012), we would expect that Case 2, with fewer land covers than Case 3 but a greater extent of land covers supplying each ES, would offer greater overall resilience in ES supply than would Case 3, which has a greater diversity of ESs but low redundancy. Because the entire ES-supply space may include areas that do not correspond to any configuration of ESs, this approach is best applied to comparisons of landscapes rather than as an absolute measure of ESs in one location.

Finally, mapping ESs in multidimensional land-cover or land-use space (e.g. Fig. 1) allows the identification of ES bundles that respond similarly to land cover/land use. These bundles can then be used to identify management decisions that minimize disruption of service flows. For example, ESs related to the soil subsystem clustered together (e.g. global climate regulation was closely linked to nutrient cycling; Fig. 1), likely due to several indicators being shared by both (Supplementary Data Set S4). There was also a gap in our database with respect to the contribution of vegetation and livestock to greenhouse gas fluxes because, in New Zealand, these contributions are well studied within a given land cover, but the lack of comparisons across land covers/uses limited our ability to quantify changes in this service.

In New Zealand, production land covers are dominant, with exotic forests, high-producing exotic grasslands, croplands, and orchards/vineyards occupying $42 \%$ of the country's terrestrial area in 2012 (Landcare Research, 2015). Our assessment, like other ES assessments elsewhere (Costanza et al., 2014), shows that decisions on ecosystem management (such as those leading to the dominance of production land covers) reflect prioritization of a set of ESs over others. Specifically, the trade-offs we find between production and low- or no-production land covers illustrate how the preference for ESs with a high market value and shortterm returns occurs at the expense of ESs that have no market value but are essential for sustained, long-term human well-being (Rodríguez-Loinaz, Alday \& Onaindia, 2015).

The above findings resonate with the recommendations of Foley et al. (2011) with respect to halting indiscriminate expansion of agriculture into sensitive ecosystems. However, our findings also suggest that, at the landscape scale, the trade-offs between the ESs supplied by production and non-production land covers can not be solved with a single land cover. Even for the ESs that were best delivered by land covers with no production, we did not find evidence of a single land cover consistently performing better than the rest in the supply of all ESs. Therefore, a landscape with a mosaic of these land covers is more likely to offer a broader suite of ESs than one dominated by large extents of any single low- or no-production land cover (Fischer, Lindenmayer \& Manning, 2006; Law et al., 2015).

Thus, we support earlier recommendations to extend beyond the dichotomy of conservation versus production land into a more a comprehensive management (Tscharntke et al., 2005; Grau, Kuemmerle \& Macchi, 2013). Such management could, for example, contemplate the extension or restoration of under-represented native land uses at strategic sites where intensive use is not matched by increased production yield, to promote the supply of critical ESs or broaden the existing suite. To this end, management will need to be informed by a comprehensive understanding of how ESs can scale up from individual land-use units and how the relative sizes of different land-use units within a landscape can affect ES supply.

Our analysis shows that low-intensity production land covers that retain some native vegetation (i.e. the low-producing grasslands in our data set) can approach native land covers (indigenous forests) in terms of overall ES supply. These low-intensity 
production land covers demonstrate that production and a suite of other ESs can be jointly delivered, providing empirical support to the notion of managed ecosystems with 'restored' ESs proposed by Foley et al. (2005). Importantly, we identified great variability in how land covers supplied certain ESs, despite there being high replication in our evidence base for these effects (e.g. erosion control by high-producing exotic grasslands, indigenous and exotic forests). This suggests that local environmental conditions (e.g. slope) and management practices can significantly alter how a given land use affects ES supply (Felipe-Lucia et al., 2018). In turn, this implies some potential to improve ES supply by adjusting management practices within specific land uses (Guerra \& Pinto-Correia, 2016; Pang et al., 2017) or incorporating local environmental conditions better into land-use decisions. Within individual land uses, decisions on which practices to adopt will require detailed research on the effects of different management regimes on ES supply (Guerra \& PintoCorreia, 2016; Maseyk, Dominati \& Mackay, 2018), as well as an understanding of the extent to which the plasticity in ES supply is constrained (or favoured) by environmental factors.

A critical challenge in applying the ESs framework to spatial and environmental planning is understanding the extent to which different land uses affect ES supply (Braat \& de Groot, 2012). The uneven coverage of different ESs that we observed in the literature reflects both variation in the difficulty of quantifying the supply for different ESs and the likely relevance of comparing the supply of certain ESs among land uses. Within our data set, supporting and regulating ESs are best represented. In the global literature, regulating ESs are also the most commonly quantified and mapped category, however, they are usually followed by provisioning ESs, while the evidence on supporting ESs is scarce (Martínez-Harms \& Balvanera, 2012; Crossman et al., 2013; Howe et al., 2014; Malinga et al., 2015). The limited representation of provisioning ESs in our data set possibly occurred because most provisioning ESs (e.g. milk, timber) are linked to single or a few land covers and, consequently, are unlikely to be compared across land covers. Such services, however, enter the market directly and can be quantified more readily in monetary terms. By contrast, the supporting and regulating ESs that predominate in our data set usually translate to externalities in the context of production systems, and are more likely to be quantified through biophysical indicators than monetary units (Howe et al., 2014; Czúcz et al., 2018).

Cultural ESs are poorly represented in our database, with the few indicators for this category all being shared with the capture fisheries provisioning service, because they pertain to eels, which are of cultural significance to Māori in New Zealand. Cultural ESs encompass a diverse set of services and have non-material and ideological dimensions that are not readily quantified. The comprehensive methodologies and frameworks that have recently been introduced to quantify the supply of cultural ESs include the use of cultural texts and materials (e.g. paintings, songs, literary texts) as evidence for these services (Cabana et al., 2020). Future ES assessments may therefore benefit from combining our approach (based on quantitative evidence) with these recent developments focusing on the evidence in cultural materials and representations. In addition, aesthetic value (which is a subset of cultural ESs) may be captured by differences in land values, although land value (for example of a farm) may be influenced by adjacent land covers, rather than pertaining to the land cover that provides the service (e.g. a natural area). Such impacts would be difficult to capture with land cover comparisons like those we used, although they present an interesting avenue for future landscape-scale comparisons. Because the cultural ESs we quantified were specific to species known to be harvested by Māori, and to the scale of single land covers, we caution against extrapolating these findings (Fig. S36) to cultural ESs in other contexts such as recreation and aesthetics.

More generally, it has been suggested that many cultural ESs (e.g. ethical, spiritual, and inspirational values) escape the instrumental value domain present in the ESs framework. Instead, they fall under the relational domain, whereby value is not solely defined in terms of the direct benefits derived from an ecosystem, but also in terms of the social webs of desired and actual relationships constructed around that ecosystem or its components (Chan et al., 2016). However, the domain of relational values is not limited to cultural ESs and can also be found in the sense of stewardship, identity belonging and moral responsibility that people uphold when thinking of regulation, provisioning and supporting services. Consequently, a quantitative approach like ours should be complemented with assessments that address the relational dimensions of the values people hold for the natural elements and ESs in different land uses, to represent their importance better across multiple value domains (Lyver et al., 2017).

Individual ESs are defined to encompass distinct processes and values, but these are often quantified by overlapping sets of indicators (Czúcz et al., 2018). For example, in our data set indicators from water and soil pertained to more than one ES (e.g. water purification and provision of fresh water both share indicators of water quality, while erosion control and soil formation share indicators on soil stability). ES indicators can also occupy different positions in the spectrum connecting the supply and demand ends of ESs (Villamagna, Angermeier \& Bennett, 2013). Here we have focused exclusively on the supply end and, more specifically, on the capacity of land covers to provide ESs rather than on their actual flow or delivery as benefits perceived by a specific group of individuals.

Since the Millennium Ecosystem Assessment was released, there have been initiatives to redefine ESs and their categories (TEEB, 2010; CICES, 2018). Here we argue that future work in determining how best to quantify ESs, their potential and realized delivery, and their spatio-temporal variation, will be at least as important as refining their taxonomy. Furthermore, if a focus on quantifying ESs reveals aspects of services that are best left unquantified (such as the relational domain of cultural ESs), this could also lead to the development of alternative ways of assessing those ESs, which could then be applied in combination with quantitative approaches like that developed here. Recent developments, like the Society. 
concept of nature's contributions to people and the framework for their assessment proposed by Díaz et al. (2018), provide an opportunity for reconciling these issues.

Our work illustrates how existing data can be used to assess bundles and interactions across multiple ESs and land covers in a more cost-efficient way than through direct field observations of each service on each land cover. We also provide evidence of the land-cover characteristics driving ES associations across all the land covers in a temperate country. Yet, an important caveat to our approach stems from underlying factors that are correlated with land use and impact the supply of certain ESs. For example, since land uses such as forestry and natural habitats are frequently found on steep slopes, this physical characteristic will likely influence erosion control in a way that covaries with land cover. At the most extreme end, some ESs may not be related to land cover, but rather respond to other spatially variable factors (e.g. aesthetic values from housing location on hillsides). These factors were beyond the scope of our work, as we did not separate the effects of spatial factors from those of land cover. In fact, one could argue that land use is not selected independently from the local environment, so these factors are a frequent (although not universal) component of any land use and its influence on ESs. Future approaches may benefit from examining how these factors affect the between- or within-land-use differences in ES supply.

This distinction would allow a shift from comparisons across locations (as examined here), which allow comparisons of the components of existing landscapes, to the predicted impacts of land-use change on ESs at any location. However, such predictions would also need to incorporate legacy effects of past land uses, as these can have enduring consequences on ecosystem functioning (Dallimer et al., 2015; Perring et al., 2016). Similarly, for such predictions, it would be important to consider the effect of the configuration of land-use types within a landscape (see above discussion regarding aesthetic services), as this has also been shown to be an important complement to the composition (and diversity) of land covers in determining ESs (Obiang Ndong et al., 2020) and their resilience (Loreau et al., 2003; Biggs et al., 2012). Thus, there are many potential avenues to extend our approach, which opens the way for incorporating existing sources of information actively into ESs research and informing practitioners to shape land systems that sustainably support human well-being.

\section{GONGLUSIONS}

(1) Our synthesis of land cover supply of ESs in New Zealand revealed a consistent trade-off in the services supplied by high-value production land covers versus those with low or no production and native elements in their vegetation cover. While production land covers specialized in the supply of primary production, low- or no-production land covers supplied a broad array of supporting and regulating ESs. We did not find any evidence that forest cover was associated with any distinct patterns of ES supply.

(2) We show that the trade-off between ESs supplied by production and non-production land covers can not be solved with a single land cover. In contrast to earlier suggestions that a single natural ecosystem can support multiple ESs at high levels (Foley et al., 2005), our analyses reveal that a mosaic of different land covers will be required to supply multiple ESs within a landscape.

(3) We show that exploring how different land covers map on to multi-dimensional ES space allows for an assessment of how diverse and resilient different combinations of land covers can be in their supply of ESs. Such assessments can effectively support land-use planning decisions beyond considerations of the specific identity of each land cover and the ESs it supplies.

(4) We demonstrate how existing data can be used to assess ES bundles and, in so doing, reveal a method that is more cost-efficient than direct field observations for incorporating fine-scale detail into comprehensive, nationwide assessments of ES supply across multiple land covers. However, we also find that effective landscape management of ESs will require further research on how environmental and land-management factors can mediate the effects of land use on ES supply, and how spatial patterning determines cross-habitat service supply. We anticipate that these effects will differ across ESs and will be more pronounced for ESs where there is high variability in supply by individual land covers (e.g. erosion control in our data set).

\section{AGKNOWLEDGEMENTS AND AUTHOR CONTRIBUTIONS}

We thank Melanie Hamzah for her assistance in abstract screening and Sol Heber, Sophie Hunt, Jessica Furlong and Matthew Scott for their help with full-text assessment and data extraction to collate our data set. We also thank thematic experts Karen L. Adair (soil microbiology), Catherine M. Febria (freshwater ecology), Leo Condron (soil biogeochemistry), Matthew Turnbull (plant physiological ecology) and Angus McIntosh (freshwater ecology) for help with interpreting potential ecosystem service indicators. We are grateful to Daniel Stouffer and Melissa Ann Broussard for their valuable technical advice and members of the Stouffer and Tylianakis lab groups for their comments and useful discussions. The manuscript benefitted from helpful comments by Neville Crossman, Pita Verwij, and two anonymous reviewers. This work was funded by the Ministry of Business, Innovation and Employment, NZ programme BEST: Building biodiversity into an ecosystem service-based approach for resource management (C09X1307). We thank Suzie Greenhalgh for coordinating this programme and providing helpful discussions. Likewise, we thank the members of 
the programme's steering committee for their valuable suggestions during the planning and exectuion of our research.

Author contributions: J.M.T., E.G.B. and C.G.-G. conceived and developed the original project concept; J.M.T. and E.G.B. secured funding for the project; all authors contributed to study design; data was acquired by C.G.-C., with input from J.M.T. and E.G.B.; G.G.-C., J.M.T., S.N. and M.L. contributed to the data analysis; G.G.-G. drafted the manuscript; J.M.T., S.N., M.L. and E.G.B. made revisions and critical appraisals.

\section{REFERENGES}

References marked with $\bowtie$ are cited in the supplementary methods and results, references marked with $\uparrow$ correspond to the studies used as input for our meta-analysis and references marked with + support our allocation of indicators to ecosystem services (presented in Supplementary Data Set S4). \$Adams, M. L., Davis, M. R. \& Powell, K. J. (2001). Effects of grassland afforestation on exchangeable soil and soil solution aluminium. Australian fournal of Soil Research 39, 1003-1014.

$†$ Ahmad, M. S. A. \& Ashraf, M. (2012). Essential roles and hazardous effects of nickel in plants. In Reviewes of Environmental Contamination and Toxicology (ed. D. WhiTACRE), pp. 125-167.Springer Netherlands, Dordrecht.

$\dagger$ Al Mansouri, H. M. \& Alhendawi, R. A. M. (2014). Effect of increasing concentration of bicarbonate on plant growth and nutrient uptake by maize plants. American-Eurasian Fournal of Agricultural and Environmental Sciences 14, 1-6.

Aldana Domínguez, J., Ignacio, P., Jorgelina, G. A., Cecilia, A. S. Carlos, M. \& Francisco, N. (2019). Assessing the effects of past and future land cover changes in ecosystem services, disservices and biodiversity: a case study in Barranquilla metropolitan area (BMA), Colombia. Ecosystem Services 37, 100915.

Ament, J. M., Moore, C. A., Herbst, M. \& Cumming, G. S. (2017). Cultural ecosystem services in protected areas: understanding bundles, trade-offs, and synergies. Conservation Letters 10, 439-449.

†American Meteorological Society (2012). Specific discharge - glossary of meteorology. http://glossary.ametsoc.org/wiki/specific discharge .

Andrew, M. E., Wulder, M. A., Nelson, T. A. \& Coops, N. C. (2015). Spatial data, analysis approaches, and information needs for spatial ecosystem service assessments: a review. GIScience \&0 Remote Sensing 52, 344-373.

$\dagger$ ANDREws, S. \& WANDER, M. (2011 la) Soil functions: biodiversity and habitat. http:// soilquality.org/functions/biodiversity.html .

†Andrews, S. \& WAnder, M. (2011b) Aggregate stability. http://soilquality.org/ indicators/aggregate_stability.html .

¥Aslam, T., Choudhary, M. A. \& SAgGar, S. (1999). Tillage impacts on soil microbial biomass $\mathrm{C}, \mathrm{N}$ and $\mathrm{P}$, earthworms and agronomy after two years of cropping following permanet pasture in New Zealand. Soil and Tillage Research 51, 103-111.

\#BAILlie, B. R. \& Davies, T. R. (2002). Effects of land use on the channel morphology of streams in the Moutere gravels, Nelson, New Zealand. Fournal of Hydrology New Zealand 41, 19-45.†

$†$ Bakshi, A. \& Panigrahi, A. K. (2018). A comprehensive review on chromium induced alterations in fresh water fishes. Toxicology Reports 5, 440-447.

$†$ BaLL, J. (1999). Understanding and correcting soil acidity. https://www.noble.org/ news/publications/ag-news-and-views/1999/january/understanding-andcorrecting-soil-acidity/

Bateman, I. J., Harwood, A. R., Mace, G. M., Watson, R. T., Abson, D. J., Andrews, B., Binner, A., Crowe, A., Day, B. H., Dugdale, S., Fezzi, C., Foden, J., Hadley, D., Haines-Young, R., Hulme, M., et al. (2013). Bringing ecosystem services into economic decision-making: land use in the United Kingdom. Science $341,45-50$.

†Battin, T. J., Besemer, K., Bengtsson, M. M., Romani, A. M. \& Packmann, A. I. (2016). The ecology and biogeochemistry of stream biofilms. Nature Reviewes Microbiology 14, 251-263.

\# Bellingham, P. J. \& Coomes, D. A. (2003). Grazing and community structure as determinants of invasion success by scotch broom in a New Zealand montane shrubland. Diversity and Distributions 9, 19-28.

$\dagger$ Berg, M. \& Miranda, M. (2018). Phosphorus behaviour in the environment. https://www.ag.ndsu.edu/publications/environment-natural-resources/ phosphorus-behavior-in-the-environment .

\# Bergin, D. O., Kimberley, M. O. \& Marden, M. (1995). Protective value of regenerating tea tree stands on erosion-prone hill country, East Coast, North Island, New Zealand. New Zealand Fournal of Forestry Science 25, 3-19.
†Bhadauria, T. \& Saxena, K. G. (2010). Role of earthworms in soil fertility maintenance through the production of biogenic structures. Applied and Environmental Soil Science 2010, 816073.

Biggs, R., Schlüter, M., Biggs, D., Bohensky, E. L., Burnsilver, S., Cundill, G., Dakos, V., Daw, T. M., Evans, L. S., Kotschy, K. Leitch, A. M., Meek, C., Quinlan, A., Raudsepp-Hearne, C., Robards, M. D., et al. (2012). Toward principles for enhancing the resilience of ecosystem services. Annual Review of Environment and Resources 37, 421-448.

$\dagger$ BLuE, M.L. (2017). How to calculate erosion rate. https://sciencing.com/calculateerosion-rate-61 18473.html

†Boothroyd, I. K. G., Quinn, J. M., Langer, E. R., Costley, K. J. \& STEWARD, G. (2004). Riparian buffers mitigate effects of pine plantation logging on New Zealand streams: 1. Riparian vegetation structure, stream geomorphology and periphyton. Forest Ecology and Management 194, 199-213.

††Boulton, A. J., Scarsbrook, M. R., Quinn, J. M. \& Burrell, G. P. (1997) Land-use effects on the hyporheic ecology of five small streams near Hamilton, New Zealand. New Zealand fournal of Marine and Freshwater Research 31, 609-622.

BraAt, L. C. \& DE Groot, R. S. (2012). The ecosystem services agenda: bridging the worlds of natural science and economics, conservation and development, and public and private policy. Ecosystem Services 1, 4-15.

\$Broad, T. L., Townsend, C. R., Closs, G. P. \& Jellyman, D. J. (2001). Microhabitat use by longfin eels in New Zealand streams with contrasting riparian vegetation. Fournal of Fish Biology 59, 1385-1400.

\$Broad, T. L., Townsend, C. R., Closs, G. P. \& Jellyman, D. J. (2002). Riparian land use and accessibility to fishers influence size class composition and habitat use by longfin eels in a New Zealand river. Fournal of Fish Biology 61, 1489-1503.

$\nmid$ Brodie, R.S. \& HostetLER, S. (2005). A review of techniques for analysing baseflow from stream.

\$†Roekhuizen, N. \& QUinN, J. M. (1998). Influences of stream size and catchment land-use on fine particulate organic matter retention in streams. New Zealand foumal of Marine and Freshwater Research 32, 581-590.

Cabana, D., Ryfield, F., Crowe, T. P. \& Brannigan, J. (2020). Evaluating and communicating cultural ecosystem services. Ecosystem Services 42, 101085.

‡Cadbury, S. L., Hannah, D. M., Milner, A. M., Pearson, C. P. \& Brown, L. E (2008). Stream temperature dynamics within a New Zealand glacierized river basin. River Research and Applications 24, 68-89.

†Carson, J. \& Phillips, L. (2019). Soil nitrogen supply. http://soilquality.org.au/ factsheets/soil-nitrogen-supply.

†CArson, J. (2019). Microbial biomass carbon - New South Wales. http://soilquality. org.au/factsheets/microbial-biomass-carbon-nsw

\$Carswell, F. E., Burrows, L. E. \& Mason, N. W. H. (2009). Above-Ground Carbon Sequestration by Early-Successional Woody Vegetation: A Preliminary Analysis - Science for Conservation 297, p. 20. Department of Conservation, Wellington.

CEE (2013). Guidelines for systematic review and evidence synthesis in environmental management - version 4.2. Centre for Evidence Based Conservation. http://www environmentalevidence.org/wp-content/uploads/2014/06/review-guidelinesversion-4.2-final.pdf.

Chan, K. M. A., Balvanera, P., Benessaiah, K., Chapman, M., Díaz, S., Gómez-Baggethun, E., Gould, R., Hannahs, N., Jax, K., Klain, S., Luck, G. W., Martín-López, B., Muraca, B., Norton, B., Ott, K., et al. (2016). Opinion: why protect nature? Rethinking values and the environment. Proceedings of the National Academy of Sciences of the United States of America 113, $1462-1465$

Chaudhary, S., McGregor, A., Houston, D. \& Chettri, N. (2015). The evolution of ecosystem services: a time series and discourse-centered analysis. Environmental Science and Policy 54, 25-34.

‡Chen, C. R., Condron, L. M., Davis, M. R. \& Sherlock, R. (2003) Seasonal changes in soil phosphorus and associated microbial properties under adjacent grassland and forest in New Zealand. Forest Ecology and Management 177, 539-557.

Chen, W., ChI, G. \& LI, J. (2019). The spatial association of ecosystem services with land use and land cover change at the county level in China, 1995-2015. Science of the Total Environment 669, 459-470.

‡Choudhary, M., Akramkhanov, A. \& Saggar, S. (2002). Nitrous oxide emissions from a New Zealand cropped soil: tillage effects, spatial and seasonal variability. Agriculture, Ecosystems \&̊ Environment 93, 33-43.

CICES (2018). Common international classification of ecosystem services (CICES) V5.1 (January 2018). https://cices.eu/ .

$\dagger$ Close, E. A. \& Powell, H. J. K. (1989). Rapidly extracted $\left(0.02 \mathrm{~m} \mathrm{CaCl}_{2}\right.$ - soluble $)$ reactive aluminum as a measure of aluminum toxicity in soils. Australian fournal of Soil Research 27, 663-672.

†Commonwealth of Kentucky Water Watch (2019). Nitrate - nitrite nitrogen. http://www.state.ky.us/nrepc/water/wcpno.htm .

Cord, A. F., Bartkowski, B., Beckmann, M., Dittrich, A., HermansNeumann, K., Kaim, A., Lienhoop, N., Locher-Krause, K., Priess, J., Schröter-Schlaack, C., Schwarz, N., Seppelt, R., Strauch, M., 
VÁclavík, T. \& VolK, M. (2017). Towards systematic analyses of ecosystem service trade-offs and synergies: Main concepts, methods and the road ahead. Ecosystem Services 28, 264-272.

$\dagger$ Corell, D. L. (1998). The role of phosphorus in the eutrophication of receiving waters: a review. Fournal of Environmental Quality 27, 261-266.

Costanza, R., de Groot, R. S., Sutton, P., van der Ploeg, S., Anderson, S. J., Kubiszewski, I., Farber, S. \& Turner, R. K. (2014). Changes in the global value of ecosystem services. Global Environmental Change 26, 152-158.

†Cotching, W. E., Allbrook, R. F. \& Gibbs, H. S. (1979). Influence of maize cropping on the soil structure of two soils in the Waikato district, New Zealand. New Zealand Journal of Agricultural Research 22, 431-438.

Craig, J., Anderson, S., Clout, M., Creese, B., Mitchell, N., Ogden, J., Roberts, M. \& Ussher, G. (2000). Conservation issues in New Zealand. Annual Review of Ecology, Evolution and Systematics 31, 61-78.

$\dagger$ Crohn, D. (2004). Nitrogen mineralization and its importance in organic waste recycling. In Proceedings National Alfalfa Symposium, pp. 13-15.University of California, Davis, San Diego.

Crossman, N. D., Burkhard, B., Nedkov, S., Willemen, L., Petz, K., Palomo, I., Drakou, E. G., Martín-López, B., McPhearson, T., Boyanova, K., Alkemade, R., Egoh, B., Dunbar, M. B. \& Maes, J. (2013). A blueprint for mapping and modelling ecosystem services. Ecosystem Services 4, 4-14.

Czúcz, B., Arany, I., Potschin-Young, M., Bereczki, K., Kertész, M., Kiss, M., Aszalós, R. \& Haines-Young, R. (2018). Where concepts meet the real world: a systematic review of ecosystem service indicators and their classification using CICES. Ecosystem Services 29, 145-157.

Dade, M. C., Mitchell, M. G. E., McAlpine, C. A. \& Rhodes, J. R. (2019). Assessing ecosystem service trade-offs and synergies: the need for a more mechanistic approach. Ambio 48, 1116-1128.

Dale, V. H., Brown, S., Haeuber, R. A., Hobbs, N. T., Huntly, N., Naiman, R. J., Riebsame, W. E., Turner, M. G. \& Valone, T. J. (2000). Ecological principles and guidelines for managing the use of land. Ecological Applications 10, 639-670.

Dallimer, M., Davies, Z. G., Diaz-Porras, D. F., Irvine, K. N., Maltby, L., Warren, P. H., Armsworth, P. R. \& Gaston, K. J. (2015). Historical influences on the current provision of multiple ecosystem services. Global Environmental Change 31, 307-317.

$\ddagger$ Davies-Colley, R. J. \& Quinn, J. M. (1998). Stream lighting in five regions of North Island, New Zealand: control by channel size and riparian vegetation. New Zealand Fournal of Marine and Freshwater Research 32, 591-605.

$\ddagger$ DAvies-Colley, R. J. (1997). Stream channels are narrower in pasture than in forest. New Zealand Fournal of Marine and Freshwater Research 31, 599-608.

$¥ \dagger$ Davis, M. R. \& LANG, M. H. (1991). Increased nutrient availability in topsoils under conifers in the South Island high country. New Zealand Journal of Forestry Science 21, $165-179$.

$†$ DE Boer, D. H. \& Crosby, G. (1996). Specific sediment yield and drainage basin scale. In Erosion and Sediment Yield: Global and Regional Perspectives (Proceedings of the Exeter Symposium, Fuly 1996) (eds B. Weвв and D. E. Walding), pp. 333-338. International Association of Hydrological Sciences, Wallingford.

†DEATH, R. G. \& ZimmermanN, E. M. (2005). Interaction between disturbance and primary productivity in determining stream invertebrate diversity. Oikos 111, 392-402.

†Department of Conservation. (2019). Animal pests A-Z. https://www.doc.govt. nz/nature/pests-and-threats/animal-pests/

†Dewson, Z. S., James, A. B. W. \& Death, R. G. (2007). Stream ecosystem functioning under reduced flow conditions. Ecological Applications 17, 1797-1808.

Díaz, S., Pascual, U., Stenseke, M., Martín-López, B., Watson, R. T., Molnár, Z., Hill, R., Chan, K. M. A., Baste, I. A., Brauman, K. A., Polasky, S., Church, A., Lonsdale, M., Larigauderie, A., Leadley, P. W., et al. (2018). Assessing nature's contributions to people. Science 359, 270-272.

†Dodd, M. B., Quinn, J. M., Thorrold, B. S., Parminter, T. G. \& Wedderburn, M. E. (2008). Improving the economic and environmental performance of a New Zealand hill country farm catchment: 3. Short-term outcomes of land-use change. New Zealand fournal of Agricultural Research 51, 155-169.

†Donnison, A., Ross, C. \& Thorrold, B. S. (2004). Impact of land use on the faecal microbial quality of hill-country streams. New Zealand Journal of Marine and Freshwater Research 38, 845-855.

Duarte, G. T., Santos, P. M., Cornelissen, T. G., Ribeiro, M. C. \& Paglia, A. P. (2018). The effects of landscape patterns on ecosystem services: meta-analyses of landscape services. Landscape Ecology 33, 1247-1257.

†DunCAN, M. J. (1995). Hydrological impacts of converting pasture and gorse to pine plantation, and forest harvesting, Nelson, New Zealand. Fournal of Hydrology New Zealand 34, 15-41

†EDwards, E. \& Huryn, A. D. (1996). Effect of riparian land use on contributions of terrestrial invertebrates to streams. Hydrobiologia 337, 151-159.

$\dagger$ Egunjobi, J. K. (1969). Primary productivity and nutrient cycling in terrestrial ecosystems - a review with particular reference to New Zealand. Tuatara 17, 50-62. $\dagger$ Environment Agency (2007). Chapter 2. Factors that influence runoff - soil, landscape, weather and land use. In Think Soils Manual, Environment Agency, pp. 7-29.Environment Agency, Rotherham.

†Erb, K. H., Kastner, T., Plutzar, C., Bais, A. L. S., Carvalhais, N., Fetzel, T., Gingrich, S., Haberl, H., Lauk, C., Niedertscheider, M., Pongratz, J., Thurner, M. \& Luyssaert, S. (2018). Unexpectedly large impact of forest management and grazing on global vegetation biomass. Nature 553, 73-76.

†Eros, T., Gustafsson, P., Greenberg, L. A. \& Bergman, E. (2012). Foreststream linkages: effects of terrestrial invertebrate input and light on diet and growth of brown trout (Salmo trutta) in a boreal forest stream. PLoS One 7, e3646.

$\dagger$ European Environment Agency (2016). Soil moisture. https://www.eea.europa. $\mathrm{eu} /$ data-and-maps/indicators/water-retention-4 .

Ewers, R. M., Kliskey, A. D., Walker, S., Rutledge, D., Harding, J. S. \& Didham, R. K. (2006). Past and future trajectories of forest loss in New Zealand. Biological Conservation 133, 312-325.

\$FAHEY, B. D. \& JACKSON, R. J. (1997). Environmental effects of forestry at big bush Forest, South Island, New Zealand: I. Changes in water chemistry. Fournal of Hydrology New Zealand 36, 43-71.

\$FAhEy, B. D. \& WATson, A. J. (1991). Hydrological impacts of converting tussock grassland to pine plantation, Otago, New Zealand. New Zealand Fournal of Hydrology $30,1-15$.

¥Fahey, B. D., Marden, M. \& Phillips, C. J. (2003). Sediment yields from plantation forestry and pastoral farming, coastal Hawke's bay, North Island, New Zealand. Fournal of Hydrology New Zealand 42, 27-38.

Felipe-Lucia, M. R., Soliveres, S., Penone, C., Manning, P., van der Plas, F., Boch, S., Prati, D., Ammer, C., Schall, P., Gossner, M. M., Bauhus, J., Buscot, F., Blaser, S., Blüthgen, N., de Frutos, A., et al. (2018). Multiple forest attributes underpin the supply of multiple ecosystem services. Nature Communications 9, 4839.

$†$ Fenton, M., Albers, C. \& Ketterings, Q. (2008). Soil organic matter. http:// franklin.cce.cornell.edu/resources/soil-organic-matter-fact-sheet .

‡Findlay, S., Hickey, C. W. \& Quinn, J. M. (1997). Microbial enzymatic response to catchment-scale variations in supply of dissolved organic carbon. New Zealand Journal of Marine and Freshwater Research 31, 701-706.

$\dagger$ FirTh, P. (2019). Ecosystem services - water purification. http://sciencenetlinks. com/lessons/ecosystem-services-water-purification/ .

Fischer, J., Lindenmayer, D. B. \& Manning, A. D. (2006). Biodiversity, ecosystem function and resilience: ten guiding principles for off-reserve conservation. Frontiers in Ecology and the Environment 4, 80-86.

Fisher, B., Turner, R. K. \& Morling, P. (2009). Defining and classifying ecosystem services for decision making. Ecological Economics 68, 643-653.

Foley, J. A., Defries, R., Asner, G. P., Barford, C., Bonan, G., Carpenter, S. R., Chapin, F. S. I., Coe, M. T., Daily, G. C., Gibbs, H. K., Helkowski, J. H., Holloway, T., Howard, E. A., Kucharik, C. J., Monfreda, C., et al. (2005). Global consequences of land use. Science 309, 570-574.

Foley, J. A., Ramankutty, N., Brauman, K. A., Cassidy, E. S., Gerber, J. S., Johnston, M., Mueller, N. D., O’Connell, C., Ray, D. K., West, P. C., Balzer, C., Bennett, E. M., Carpenter, S. R., Hill, J., Monfreda, C., et al. (2011). Solutions for a cultivated planet. Nature 478, 337-342.

Foote, K. J., Joy, M. K. \& DeAth, R. G. (2015). New Zealand dairy farming: milking our environment for all its worth. Environmental Management 56, 709-720.

‡Francis, G. S., Bartley, K. M. \& TAbley, F. J. (1998). The effect of winter cover crop management on nitrate leaching losses and crop growth. The fournal of Agricultural Science 131, 299-308.

‡Fancis, G. S., Tabley, F. J. \& White, K. M. (1999). Restorative crops for the amelioration of degraded soil conditions in New Zealand. Australian fournal of Soil Research 37, 1017-1034.

\$Francis, G. S., Trimmer, L. A., Tregurtha, C. S., Williams, P. H. \& Butler, R. C. (2003). Winter nitrate leaching losses from three land uses in the Pukekohe area of New Zealand. New Zealand Journal of Agricultural Research 46, 215-224.

†Fraser, P. M., Curtin, D., Harrison-Kirk, T., Meenken, E. D., Beare, M. H., Tabley, F. J., Gillespie, R. N. \& Francis, G. S. (2013). Winter nitrate leaching under different tillage and Winter cover crop management practices. Soil Science Society of America fournal 77, 1391-1401.

\$Friberg, N. \& Winterbourn, M. J. (1997). Effects of native and exotic forest on benthic stream biota in New Zealand: a colonization study. Marine and Freshwater Research 48, 267-275.

††Fiberg, N., Winterbourn, M. J., Shearer, K. A. \& Larsen, S. E. (1997). Benthic communities of forest streams in the South Island, New Zealand: effects of forest type and location. Archiv für Hydrobiologie 138, 289-306.

Fründ, J., Dormann, C. F., Holzschuh, A. \& Tscharntke, T. (2013). Bee diversity effects on pollination depend on functional complementarity and niche shifts. Ecology 94, 2042-2054.

†Garibaldi, L. A., Steffan-Dewenter, I., Winfree, R., Aizen, M. A., Bommarco, R., Cunningham, S. A., Kremen, C., Carvalheiro, L. G., 
Harder, L. D., Afik, O., Bartomeus, I., Benjamin, F., Boreux, V., Cariveau, D., Chacoff, N. P., et al. (2013). Wild pollinators enhance fruit set of crops regardless of honey bee abundance. Science 339, 1608-1611.

†GERKE, J. (1994). Aluminum complexation by humic substances and aluminum species in the soil solution. Geoderma 63, 165-175.

†Gessner, M. O. \& Chauvet, E. (1994). Importance of stream microfungi in controlling breakdown rates of leaf litter. Ecology 75, 1807-1817.

$\dagger$ Ghani, A., Dexter, M. \& Perrott, K. W. (2003). Hot-water extractable carbon in soils: a sensitive measurement for determining impacts of fertilisation, grazing and cultivation. Soil Biology and Biochemistry 35, 1231-1243.

‡Ghani, A., Dexter, M., Carran, R. A. \& Theobald, P. W. (2007). Dissolved organic nitrogen and carbon in pastoral soils: the New Zealand experience. European Fournal of Soil Science 58, 832-843.

\$Giddens, K. M., Parfitt, R. L. \& Percival, H. J. (1997). Comparison of some soil properties under Pinus radiataand improved pasture. New Zealand Fournal of Agricultural Research 40, 409-416.

Godfray, H. C. J., Beddington, J. R., Crute, I. R., Haddad, L., Lawrence, D., Muir, J. F., Pretty, J., Robinson, S., Thomas, S. M. \& Toulmin, C. (2010). Food security: the challenge of feeding 9 billion people. Science 327, 812-818.

†GoEL, M. K. (2011). Runoff coefficient. In Encyclopedia of Snow, Ice and Glaciers (eds V. P. Singh, P. Singh and U. K. Haritashya), pp. 952-953.Springer Netherlands, Dordrecht.

$†$ Gough, C. M. (2011). Terrestrial primary production: fuel for life. Nature Education Knowledge $3,28$.

$\bowtie$ Graaff, M.-A., de Groenigen, K.-J., van Six, J., Hungate, B. \& van Kessel, C. (2006). Interactions between plant growth and soil nutrient cycling under elevated $\mathrm{CO}_{2}$ : a meta-analysis. Global Change Biology 12, 2077-2091.

Grau, R., Kuemmerle, T. \& Macchi, L. (2013). Beyond "land sparing versus land sharing': environmental heterogeneity, globalization and the balance between agricultural production and nature conservation. Current Opinion in Environmental Sustainability 5, 477-483.

\#Groenendijk, F. M., Condron, L. M. \& Rijkse, W. C. (2002). Effects of afforestation on organic carbon, nitrogen and sulfur concentrations in New Zealand hill country soils. Geoderma 108, 91-100.

de Groot, R. S., Brander, L., van der Ploeg, S., Costanza, R., Bernard, F., Braat, L. C., Christie, M., Crossman, N. D., Ghermandi, A., Hein, L., Hussain, S., Kumar, P., McVittie, A., Portela, R., Rodriguez, L. C., et al. (2012). Global estimates of the value of ecosystems and their services in monetary units. Ecosystem Services 1, 50-61.

Guerra, C. A. \& Pinto-Correia, T. (2016). Linking farm management and ecosystem service provision: challenges and opportunities for soil erosion prevention in Mediterranean silvo-pastoral systems. Land Use Policy 51, 54-65.

Guerry, A. D., Polasky, S., Lubchenco, J., Chaplin-Kramer, R., Daily, G. C., Griffin, R., Ruckelshaus, M., Bateman, I. J., Duraiappah, A., Elmovist, T., Feldman, M. W., Folke, C., Hoekstra, J., Kareiva, P. M., Keeler, B. L., et al. (2015). Natural capital and ecosystem services informing decisions: from promise to practice. Proceedings of the National Academy of Sciences of the United States of America 112, 7348-7355.

\#HAASE, M. (2003). Clinal variation in shell morphology of the freshwater gastropod Potamopyrgus antipodarum along two hill-country streams in New Zealand. Fournal of the Royal Society of New Zealand 33, 549-560.

\#HaLL, M. J., Closs, G. P. \& RiLEY, R. H. (2001). Relationships between land use and stream invertebrate community structure in a South Island, New Zealand, coastal stream catchment. New Zealand Journal of Marine and Freshwater Research 35, 591-603.

\#Harding, J. S., Claassen, K. \& Evers, N. (2006). Can forest fragments reset physical and water quality conditions in agricultural catchments and act as refugia for forest stream invertebrates? Hydrobiologia 568, 391-402.

¥Harris, R. J., Thomas, C. D. \& Moller, H. (1991). The influence of habitat use and foraging on the replacement of one introduced wasp species by another in New Zealand. Ecological Entomology 16, 441-448.

\$HArris, R. J., Toft, R. J., Dugdale, J. S., Williams, P. A. \& Rees, J. S. (2004). Insect assemblages in a native (kanuka - Kunzea ericoides) and an invasive (gorse - Ulex europaeus) shrubland. New Zealand fournal of Ecology 28, 35-47.

\#Hewitt, A., Forrester, G., Fraser, S., Hedley, C. B., Lynn, I. \& Payton, I. (2012). Afforestation effects on soil carbon stocks of low productivity grassland in New Zealand. Soil Use and Management 28, 508-516.

\$Hicks, B. J. \& MCCAughan, H. M. C. (1997). Land use, associated eel production, and abundance of fish and crayfish in streams in Waikato, New Zealand. New Zealand Journal of Marine and Freshwater Research 31, 635-650.

\$Holdsworth, D. K. \& Mark, A. F. (1990). Water and nutrient input:output budgets: effects of plant cover at seven sites in upland snow tussock grasslands of eastern and Central Otago, New Zealand. Foumal of the Royal Society of New Zealand $20,1-24$.

$\dagger$ Hoorman, J.J. \& IsLam, R. (2019). Understanding soil microbes and nutrient recycling. https://ohioline.osu.edu/factsheet/sag-16
Hosking, W. J., Caple, I. W., Halpin, C. G., Brown, A. J., Paynter, D. I, Conley, D. N. \& North-Coombes, P. L. (1986). Trace Elements for Pastures and Animals in Victoria, p. 69. Department of Agriculture, Rural Affairs, Melbourne

†House, J., Brovkin, V., Betts, R., Constanza, R., Silva Dias, M. A., Holland, B., Le Quéré, C., Nophea, K. P., Riebesell, U. \& Scholes, M. (2005). Chapter 13: climate and air quality. In Ecosystems and Human Well-Being: Current State and Trends Assessment (eds R. Hassan, R. Scholes and A. Nevilue), pp. 355-390.Island Press, Washington, DC.

Howe, C., Suich, H., Vira, B. \& Mace, G. M. (2014). Creating win-wins from trade-offs? Ecosystem services for human well-being: a meta-analysis of ecosystem service trade-offs and synergies in the real world. Global Environmental Change $\mathbf{2 8}$ 263-275.

\$Hughes, A. O., Quinn, J. M. \& McKergow, L. A. (2012). Land use influences on suspended sediment yields and event sediment dynamics within two headwater catchments, Waikato, New Zealand. New Zealand Fournal of Marine and Freshwater Research 46, 315-333.

†Hyland, C., Ketterings, Q., Dewing, D., Stockin, K., Czymmek, K., Albrecht, G. \& Geohring, L. (2005). Phosphorus basics - the phosphoru cycle. http://nmsp.cals.cornell.edu/publications/factsheets/factsheet12.pdf .

†Innes, J. G., King, C. M., FluX, M. \& Kimberley, M. O. (2001). Population biology of the ship rat and Norway rat in Pureora forest park, 1983-87. New Zealand Journal of Zoology 28, 57-78.

$\dagger$ International Plant Nutrition Institute (2019a) Denitrification - nitrogen notes number 5. https://www.ipni.net/publication/nitrogen-en.nsf/0/ 668099AE825517CB85257DD600054B8C/\$FILE/NitrogenNotes-EN-5.pdf .

$\dagger$ International Plant Nutrition Institute (2019b) Nitrification - nitrogen notes number 4. https://www.ipni.net/publication/nitrogen-en.nsf/0/ 7F7F448C4D064A5985257C13004C83A3/\$FILE/NitrogenNotes-EN-04.pdf .

Jacobs, S., Burkhard, B., van Daele, T., Staes, J. \& Schneiders, A. (2015). 'The matrix reloaded': a review of expert knowledge use for mapping ecosystem services. Ecological Modelling 295, 21-30.

\$JACOBSEN, L.B. (2012). Interacting effects of land use and landscape context on wild bees (Apoidea) in Canterbury, New Zealand. PhD thesis, University of Copenhagen.

†Jarvis, N., Koestel, J., Messing, I., Moeys, J. \& Lindahl, A. (2013). Influence of soil, land use and climatic factors on the hydraulic conductivity of soil. Hydrology and Earth System Sciences 17, 5185-5195.

†Jewell, T. \& McQueEn, S. (2007). Habitat Characteristics of Jewelled Gecko (Naultinus gemmeus) Sites in Dry Parts of Otago. Science \& Technical Publishing Department of Conservation; Department of Conservation, Wellington.

†johnson, C., Albrecht, G., Ketterings, Q., Beckman, J. \& Stockin, K. (2005). Nitrogen basics - the nitrogen cycle. http://cceonondaga.org/resources/ nitrogen-basics-the-nitrogen-cycle .

†Johnson, P. A. (2006). Assessing Stream Channel Stability at Bridges in Physiographic Regions -ReportNo. FHWA-HRT-05-072. United States Department of Transportation, State College.

†Kasai, M., Brierley, G. J., Page, M. J., Marutani, T. \& Trustrum, N. A. (2005). Impacts of land use change on patterns of sediment flux in Weraamaia catchment, New Zealand. Catena 64, 27-60.

$\dagger$ Khan, M. A., Khan, S., Khan, A. \& Alam, M. (2017). Soil contamination with cadmium, consequences and remediation using organic amendments. Science of the Total Environment 601-602, 1591-1605.

†Knox, C. D., Cree, A. \& Seddon, P. J. (2012). Direct and indirect effects of grazing by introduced mammals on a native, arboreal gecko (Naultinus gemmeus). Fournal of Herpetology 46, 145-152.

†KowALSICK, T. (2002). Liming acid soils. http://rocklandcce.org/resources/limingacid-soils .

LALiberte, E. \& LegENdRe, P. (2010). A distance-based framework for measuring functional diversity from multiple traits. Ecology 91, 299-305.

Lambin, E. F. \& Meyfroidt, P. (2011). Global land use change, economic globalization, and the looming land scarcity. Proceedings of the National Academy of Sciences of the United States of America 108, 3465-3472.

†LAND Air Water Aotearoa (2019a) Dissolved inorganic nitrogen (DIN). https:// www.lawa.org.nz/learn/glossary/d/dissolved-inorganic-nitrogen-din/ .

†LAND Air Water Aotearoa(2019b) Total nitrogen. https://www.lawa.org.nz/ learn/glossary/t/total-nitrogen-tn/.

LANDCARE ReSEARch (2015). Land cover database version 4.1, mainland New Zealand. Land Resource Information Systems Portal. http://www.lcdb. scinfo.org.nz/home.

†LARsen, I. J., Montgomery, D. R. \& Korup, O. (2010). Landslide erosion controlled by hillslope material. Nature Geoscience 3, 247-251.

$\bowtie$ †Lavelle, P., Dugdale, R., Scholes, R., Berhe, A., Carpenter, E., Codispoti, L., Izac, A., Lemoalle, J., Luizao, F., Scholes, M., Treguer, P. \& WARD, B. (2005b). Chapter 12: nutrient cycling. In Ecosystems and Human Well-Being: Current State and Trends Assessment (eds R. Hassan, R. Scholes and A. NevilleE), pp. 333-353.Island Press, Washington, DG. 
Law, E. A., Meijaard, E., Bryan, B. A., Mallawaarachchi, T., Koh, L. P. \& Wilson, K. A. (2015). Better land-use allocation outperforms land sparing and land sharing approaches to conservation in Central Kalimantan, Indonesia. Biological Conservation 186, 276-286.

Lee, H. \& Lautenbach, S. (2016). A quantitative review of relationships between ecosystem services. Ecological Indicators 66, 340-351.

† Leisnham, P. T., Slaney, D. P., Lester, P. J. \& Weinstein, P. (2005). Increased larval mosquito densities from modified landuses in the Kapiti region, New Zealand: vegetation, water quality, and predators as associated environmental factors. EcoHealth 2, 313-322.

$\bowtie$ Lewis, S. \& Clarke, M. (2001). Forest plots: trying to see the wood and the trees. British Medical Fournal 322, 1479-1480.

† Linklater, W. \& Winterbourn, M. J. (1993). Life histories and production of two trichopteran shredders in New Zealand streams with different riparian vegetation. New Zealand Journal of Marine and Freshwater Research 27, 61-70.

$\dagger$ LipcZYNSKa-Kochany, E. (2018). Effect of climate change on humic substances and associated impacts on the quality of surface water and groundwater: a review. Science of the Total Environment 640-641, 1548-1565.

Loreau, M., Mouquet, N. \& Gonzalez, A. (2003). Biodiversity as spatial insurance in heterogeneous landscapes. Proceedings of the National Academy of Sciences of the United States of America 100, 12765-12770.

$\dagger$ Luo, Y. \& ZHOU, X. (2006). Importance and roles of soil respiration. In Soil Respiration and the Environment, pp. 17-32. Burlington, Vermont: Academic Press.

Lyver, P. O. B., Timoti, P., Jones, C. J., Richardson, S. J., Tahi, B. L. \& GREENHALGH, S. (2017). An indigenous community-based monitoring system for assessing forest health in New Zealand. Biodiversity and Conservation 26, 3183-3212.

$\bowtie$ MacLeOd, C. J. \& Moller, H. (2006). Intensification and diversification of New Zealand agriculture since 1960: an evaluation of current indicators of land use change. Agriculture, Ecosystems and Environment 115, 201-218.

$\ddagger$ MacLeod, C. J., Parish, D. M. B. \& Robinson, R. A. (2007). Niche opportunities and introduced birds temporal variation in resource abundance. In Temporal Dimensions of Landscape Ecology (eds J. A. Bissonette and I. Storch), pp. 252-268. Springer US, New York.

Maechler, M., Rousseeuw, P., Struyf, A., Hubert, M., Hornik, K., Studer, M., Roudier, P. \& Gonzalez, J. (2019). Package cluster - "Finding groups in data": Cluster analysis extended. https://cran.r-project.org/web/ packages/cluster/index.html.

$\ddagger$ MAHMOOD, B. \& WALL, G. L. (2001). The environmental impact of sewage effluent irrigation onto land - a case study in New Zealand. International Agricultural Engineering fournal 10, 209-230.

†MAlborough District Council (2017). Surface water quality - monitoring 2017. https://www.marlborough.govt.nz/repository/libraries/id: 1w1mps0ir17q9sgxanf9/hierarchy/Documents/Environment/ RiversandWetlands2017Reports/Surface_Water_Quality_2017_Snapshot.pdf Accessed 18.06.2019.

Malinga, R., Gordon, L. J., Jewitt, G. \& Lindborg, R. (2015). Mapping ecosystem services across scales and continents - a review. Ecosystem Services 13, 57-63.

$†$ Manaaki Whenua Landcare Research (2019a) Wasp web: information on vespula wasps in New Zealand - biodiversity impacts. https://www. landcareresearch.co.nz/science/plants-animals-fungi/animals/invertebrates/ invasive-invertebrates/wasps/impact/biodiversity

$†$ ManaAki Whenua Landcare ReSEARCH (2019b) Mineralisable N - SINDI: soil quality indicators. https://sindi.landcareresearch.co.nz/content/helpmineralisablen.html .

$†$ Manaaki Whenua Landcare Research (2019c) Olsen P - SINDI: soil quality indicators. https://sindi.landcareresearch.co.nz/content/helpolsenp.html .

$†$ Manaaki Whenua Landcare Research (2019d) Total N - SINDI: soil quality indicators. https://sindi.landcareresearch.co.nz/content/helptotaln.html .

$†$ Maraldo, K., Schmelz, R. M., Larsen, T., Christensen, B. T. \& Eriksen, J. (2015). Enchytraeids as indicator of soil quality in temporary organic grass-clover leys under contrasting management: a feasibility study. Soil Biology and Biochemistry 91, 32-39.

†MARK, A. F. \& RowLEY, J. (1976). Water yield of low-alpine snow tussock grassland in Central Otago. Fournal of Hydrology New Zealand 15, 59-79.†

Martínez-Harms, M. J. \& Balvanera, P. (2012). Methods for mapping ecosystem service supply: a review. International fournal of Biodiversity Science, Ecosystem Services ¿®" Management 8, 17-25.

Maseyk, F. J. F., Dominati, E. J. \& Mackay, A. D. (2018). Change in ecosystem service provision within a lowland dairy landscape under different riparian margin scenarios. International Fournal of Biodiversity Science, Ecosystem Services and Management 14, 17-31.

$†$ MCCauley, A., Jones, C. \& Olson-Rutz, K. (2017). Soil pH and organic matter. http://landresources.montana.edu/nm/documents/nm8.pdf .

$\ddagger$ MCDowell, R. W. \& STEwarT, I. (2006). The phosphorus composition of contrasting soils in pastoral, native and forest management in Otago, New Zealand: sequential extraction and31P NMR. Geoderma 130, 176-189.
\#McDowell, R. W. (2006). Phosphorus and sediment loss in a catchment with Winter forage grazing of cropland by dairy cattle. Fournal of Environment Quality 35, 575-583. \$McDowell, R. W., Derwry, J. J., Muirhead, R. W. \& Paton, R. J. (2003). Cattle treading and phosphorus and sediment loss in overland flow from grazed cropland. Australian Fournal of Soil Research 41, 1521-1532. †

\$Mclaren, R. G., Clucas, L. M., Taylor, M. D. \& Hendry, T. (2003). Leaching of macronutrients and metals from undisturbed soils treated with metal-spiked sewage sludge. 1. Leaching of macronutrients. Australian Fournal of Soil Research 41, 571-588.

\$Mclaren, R. G., Clucas, L. M., Taylor, M. D. \& Hendry, T. (2004). Leaching of macronutrients and metals from undisturbed soils treated with metal-spiked sewage sludge. 2. Leaching of metals. Australian Fournal of Soil Research 42, 459-471.

¥Mclay, C. D. A., Dragten, R., Sparling, G. P. \& Selvarajah, N. (2001). Predicting groundwater nitrate concentrations in a region of mixed agricultural land use: a comparison of three approaches. Environmental Pollution 115, 191-204.

\$McQueen, D. J. \& Shepherd, T. G. (2002). Physical changes and compaction sensitivity of a fine-textured, poorly drained soil (Typic Endoaquept) under varying durations of cropping, Manawatu region, New Zealand. Soil and Tillage Research 63, 93-107.

$\bowtie$ MEA (2005). Ecosystems and Human Well-Being: Synthesis. Island Press, Washington, DC.

$\dagger$ Mebane, C. A. (2010). Cadmium Risks to Freshwater Life: Derivation and Validation of LowEffect Criteria Values Using Laboratory and Field Studies - Scientific Investigations Report 2006-5245. United States Geological Survey, Reston.

†da Mendes, W. C., Alves Júnior, J., Cunha, P. C. R., da Silva, A. R., Da Evangelista, A. W. P. \& Casaroli, D. (2016). Potassium leaching in different soils as a function of irrigation depths. Revista Brasileira de Engenharia Agrícola e Ambiental 20, 972-977.

$†$ Mengel, D.B. (2019). Fundamentals of soil cation exchange capacity (CEC). https:// www.extension.purdue.edu/extmedia/ay/ay-238.html .

$\dagger$ Midwest Laboratories (2019). Nitrate and ammonium nitrogen stability and uptake. https://midwestlabs.com/wp-content/uploads/2016/11/109-nitrate-andammonium-nitrigon-stability-and-uptake.pdf .

\$ Miller, A. L., Diez, J. M., Sullivan, J. J., Wangen, S. R., Wiser, S. K., MefFin, R. \& Duncan, R. P. (2014). Quantifying invasion resistance: the use of recruitment functions to control for propagule pressure. Ecology 95, 920-929.

$†$ Moore, D. R. J. (1998). Ambient water quality criteria for organic carbon in British Columbia. Ministry of Environment, Lands; Parks, Victoria.

$\$$ Moore, T. R. (1989). Dynamics of dissolved organic carbon in forested and disturbed catchments, Westland, New Zealand. Water Resources Research 25, 1331-1339.

$\$$ Morgan, D. K. J., WaAs, J. R. \& InNES, J. (2009). An inventory of mammalian pests in a New Zealand city. New Zealand Fournal of Zoology 36, 23-33.

\$ Mosley, M. P. (1979). Sediment Sources in the Harper-Avoca Catchment - Tehnical Paper No.68. New Zealand Forest Service, Wellington.

Mouchet, M. A., Lamaroue, P., Martín-López, B., Crouzat, E., Gos, P., ByczeK, C. \& LAvorel, S. (2014). An interdisciplinary methodological guide for quantifying associations between ecosystem services. Global Environmental Change 28, 298-308.

\$Mudge, P. L., Schipper, L. A., Baisden, W. T., Ghani, A. \& Lewis, R. W. (2014). Changes in soil $\mathrm{C}, \mathrm{N}$ and $15 \mathrm{~N}$ along three forest-pasture chronosequences in New Zealand. Soil Research 52, 27-37.

\$Murphy, C. \& Robertson, A. (2000). Preliminary study of the effects of honey bees (Apis mellifera) in Tongariro National Park. Science for Conservation 139, 5-18.

\$Murphy, E. C. \& Dowding, J. E. (1994). Range and diet of stoats (Mustela erminea) in a New Zealand beech forest. New Zealand fournal of Ecology 18, 11-18.

$\dagger$ National Institute of Water and Atmospheric Research (NIWA) (2019a) Tuna - commercial fisheries. https://www.niwa.co.nz/te-kūwaha/tuna-informationresource/pressures-on-new-zealand-populations/commercial-tuna-fisheries

$†$ National Institute of Water and Atmospheric Research (NIWA) (2019b) Sediment. https://www.niwa.co.nz/our-science/freshwater/tools/kaitiaki_tools/ impacts/sediment.

$\dagger$ National Institute of Water and Atmospheric Research (NIWA) (2019c) Koura. https://www.niwa.co.nz/our-science/freshwater/tools/kaitiaki_tools/ species/koura Accessed 30.04.2019.

$\dagger$ National Research Council Committee on Copper in Drinking Water (2000). Copper in Drinking Water. National Academy Press, Washington, DC.

$\dagger$ Nayak, A. K., Rahman, M. M., Naidu, R., Dhal, B., Swain, C. K., Nayak, A. D., Tripathi, R., Shahid, M., Islam, M. R. \& Pathak, H. (2019). Current and emerging methodologies for estimating carbon sequestration in agricultural soils: a review. Science of the Total Environment 665, 890-912.

$\dagger$ Ndava, J., Diaz Llera, S. \& Manyanga, P. (2018). The future of mosquito control: the role of spiders as biological control agents: a review. International fournal of Mosquito Research 5, 6-11.

†Ne'eman, G., Jürgens, A., Newstrom-Lloyd, L., Potts, S. G. \& Dafni, A. (2010). A framework for comparing pollinator performance: effectiveness and efficiency. Biological Reviewes 85, 435-451. 
Nelson, E., Mendoza, G., Regetz, J., Polasky, S., Tallis, H., Cameron, D. R., Chan, K. M. A., Daily, G. C., Goldstein, J., Kareiva, P. M., Lonsdorf, E., Naidoo, R., Ricketts, T. H. \& Shaw, M. R. (2009). Modeling multiple ecosystem services, biodiversity conservation, commodity production, and tradeoffs at landscape scales. Frontiers in Ecology and the Environment 7, 4-11.

†New Zealand Ministry for Primary Industries (2009). Glossary - fisheries New Zealand infosite. https://fs.fish.govt.nz/page.aspx?Pk=77\&tk=298

†New Zealand Ministry for the Environment \& Stats NZ (2019). River water quality: Eschenichia coli. http://archive.stats.govt.nz/browse_for_stats/environment/ environmental-reporting-series/environmental-indicators/home/fresh water/river-water-quality-bacteria-ecoli.aspx Accessed 7.05.2019.

Nieto-Romero, M., Oteros-Rozas, E., González, J. A. \& Martín-López, B. (2014). Exploring the knowledge landscape of ecosystem services assessments in Mediterranean agroecosystems: insights for future research. Environmental Science \& Policy 37, 121-133.

$†$ Niwa, C. G., Peck, R. W. \& Torgersen, T. R. (2001). Soil, litter and coarse Woody debris habitats for arthropods in eastern Oregon and Washington. Northweest Science $75,141-148$

\$ Niyogi, D. K., Simon, K. S. \& Townsend, C. R. (2003). Breakdown of tussock grass in streams along a gradient of agricultural development in New Zealand. Freshwater Biology 48, 1698-1708.

$\dagger$ Nor, Y. M. (1981). Sulphur mineralization and adsorption in soils. Plant and Soil 60, 451-459.

$\dagger$ Noulas, C., Tziouvalekas, M. \& Karyotis, T. (2018). Zinc in soils, water and food crops. Fournal of Trace Elements in Medicine and Biology 49, 252-260.

†Novara, A., Rühl, J., La Mantia, T., Gristina, L., la Bella, S. \& TutTolomondo, T. (2015). Litter contribution to soil organic carbon in the processes of agriculture abandon. Solid Earth 6, 425-432.

\#Nyström, P., McIntosh, A. R. \& Winterbourn, M. J. (2003). Top-down and bottom-up processes in grassland and forested streams. Oecologia 136, 596-608.

†O'Brien, J. M., Warburton, H. J., Graham, S. E., Franklin, H. M., Febria, C. M., Hogsden, K. L., Harding, J. S. \& McIntosh, A. R. (2017). Leaf litter additions enhance stream metabolism, denitrification, and restoration prospects for agricultural catchments. Ecosphere 8, e02018.

¥O’Donnell, C. F. J. (2000). Influence of season, habitat, temperature, and invertebrate availability on nocturnal activity of the New Zealand long-tailed bat (Chalinolobus tuberculatus). New Zealand Journal of Zoology 27, 207-221.

†O'GeEN, A. T. (2013). Soil water dynamics. Nature Education Knoweledge 4, 9.

\#O'Loughlin, C.L., Rowe, L.K. \& Pearce, A.J. (1982). Exceptional storm influences on slope Erosion and sediment yield in Small Forest catchments, North Westland, New Zealand. In The First National Symp. On Forest Hydrology pp. 84-91. Melbourne.

Obiang Ndong, G., Therond, O. \& Cousin, I. (2020). Analysis of relationships between ecosystem services: a generic classification and review of the literature. Ecosystem Services 43, 101120

† Oertel, C., Matschullat, J., Zurba, K., Zimmermann, F. \& Erasmi, S. (2016). Greenhouse gas emissions from soils - a review. Chemie der Erde 76, 327-352.

Oksanen, J., Blanchet, F.G., Friendly, M., Kindt, R., Legendre, P., McGlinn, D., Minchin, P.R., O’Hara, R.B., Simpson, G.L., Solymos, P., Stevens, M.H.H., Szoecs, E. \& Helene, W. (2019). Package 'vegan'. https:// cran.r-project.org/web/packages/vegan/index.html.

† Oliver, G. R., Beets, P. N., Garrett, L. G., Pearce, S. H., Kimberly, M. O., Ford-Robertson, J. \& Robertson, K. A. (2004). Variation in soil carbon in pine plantations and implications for monitoring soil carbon stocks in relation to land-use change and forest site management in New Zealand. Forest Ecology and Management 203, 283-295.

$\dagger$ OrAM, B. (2019a) Dissolved oxygen in water. https://www.water-research.net/ index.php/dissovled-oxygen-in-water .

†Oram, B. (2019b) Stream water quality - importance of total suspended solids/turbidity. $\quad$ https://www.water-research.net/index.php/stream-waterquality-importance-of-total-suspended-solids-turbidity

†Oram, B. (2019c) Phosphate in surface water streams lakes. https://www.waterresearch.net/index.php/phosphate-in-water .

†ORAM, B. (2019d) Fecal coliform bacteria in water. https://www.water-research.net/ index.php/fecal-coliform-bacteria-in-water

$†$ Paller, M., Lewis, W. M., Heihinger, R. C. \& Wawronowicz, L. J. (1983). Effects of ammonia and chlorine on fish in streams recieving secondary discharges. fournal Water Pollution Control Federation 55, 1087-1097.

Pang, X., Nordström, E. M., Böttcher, H., Trubins, R. \& Mörtberg, U. (2017). Trade-offs and synergies among ecosystem services under different forest management scenarios - the LEcA tool. Ecosystem Services 28, 67-79.

$¥$ Parfitt, R. L. \& Ross, D. J. (2011). Long-term effects of afforestation with Pinus radiata on soil carbon, nitrogen, and pH: a case study. Soil Research 49, 494-503.

$†$ Parfitt, R. L. (2009). Allophane and imogolite: Role in soil biogeochemical processes. Clay Minerals 44, 135-155.
\#Parfitt, R. L., Parshotam, A. \& Salt, G. J. (2002). Carbon turnover in two soils with contrasting mineralogy under long-term maize and pasture. Australian fournal of Soil Research 40, 127-136.

†Parfitt, R. L., Percival, H. J., Dahlgren, R. A. \& Hill, L. F. (1997). Soil and solution chemistry under pasture and radiata pine in New Zealand. Plant and Soil $191,279-290$

\#Parfitt, R. L., Scott, N. A., Ross, D. J., Salt, G. J. \& Tate, K. R. (2003). Landuse change effects on soil $\mathrm{C}$ and $\mathrm{N}$ transformations in soils of high $\mathrm{N}$ status: comparisions under indigenous forest, pasture, and pine plantation. Biogeochemistry 66, 203-221.

\$Parkyn, S. M., Collier, K. J. \& Hicks, B. J. (2002). Growth and population dynamics of cravfish Paranephrops planifrons in streams within native forest and pastoral land uses. New Zealand fournal of Marine and Freshwater Research 36, 847-862.

‡Parkyn, S. M., Davies-Colley, R. J., Scarsbrook, M. R., Halliday, N. J., Nagels, J. W., Marden, M. \& Rowan, D. (2006). Pine afforestation and stream health: a comparison of land-use in two soft rock catchments, east cape, New Zealand. New Zealand Natural Sciences 31, 113-135.

$\dagger$ Paul, M. J., Walsh, B., Oliver, J. \& Thomas, D. (2019). Algal Indicators in Streams: A Review of their Application in Water Quality Management of Nutrient Pollution. U.S. Environmental Protection Agency, Washington, DC.

Perring, M. P., de Frenne, P., Baeten, L., Maes, S. L., Depauw, L., Blondeel, H., Carón, M. M. \& Verheyen, K. (2016). Global environmental change effects on ecosystems: the importance of land-use legacies. Global Change Biology 22, 1361-1371

•PETTS, G. E. (1999). River regulation BT. In Environmental Geology, pp. 521-528. Springer Netherlands, Dordrecht.

\$Prebble, M., Schallenberg, M., Carterm, J. \& Shulmeister, J. (2002). An analysis of phytolith assemblages for the quantitative reconstruction of late quaternary environments of the lower Taieri Plain, Otago, South Island, New Zealand I. Modern assemblages and transfer functions. Fournal of Paleolimnology 27, 393-413.

¥Price, S., Whitehead, D., Sherlock, R., McSeveny, T. \& Rogers, G. (2010). Net exchange of greenhouse gases from soils in an unimproved pasture and regenerating indigenous Kunzea ericoides shrubland in New Zealand. Australian Journal of Soil Research 48, 385-394.

Primack, R. B. \& INOUYE, D. W. (1993). Factors affecting pollinator visitation rates: a biogeographic comparison. Current Science 65, 257-262.

$\nmid$ Provin, T.L. \& Hossner, L.R. (2019). What happens to nitrogen in soils?https:// agrilifeextension.tamu.edu/library/gardening/what-happens-to-nitrogen-in-soils/.

†QueEnsLand Government (2006). Bank erosion. https://www.qld.gov.au/_ data/assets/pdf_file/0030/67089/what-causes-bank-erosion.pdf.

Queiroz, C., Meacham, M., Richter, K., Norström, A. V., Andersson, E. Norberg, J. \& Peterson, G. (2015). Mapping bundles of ecosystem services reveals distinct types of multifunctionality within a Swedish landscape. Ambio 44, 89-101

\$Quinn, J. M. \& STroud, M. J. (2002). Water quality and sediment and nutrient export from New Zealand hill-land catchments of contrasting land use. New Zealand Fournal of Marine and Freshwater Research 36, 409-429.

\$Quinn, J. M., BoоTHRoyd, I. K. G. \& Sмiтh, B. J. (2004). Riparian buffers mitigate effects of pine plantation logging on New Zealand streams: 2. Invertebrate communities. Forest Ecology and Management 191, 129-146.

\#Quinn, J. M., Cooper, A. B., Davies-Colley, R. J., Rutherford, J. C. \& Williamson, R. B. (1997). Land use effects on habitat, water quality, periphyton, and benthic invertebrates in Waikato, New Zealand, hill-country streams. New Zealand fournal of Marine and Freshwater Research 31, 579-597.

\#Quinn, J. M., Croker, G. F., Smith, B. J. \& Bellingham, M. A. (2009). Integrated catchment management effects on flow, habitat, instream vegetation and macroinvertebrates in Waikato, New Zealand, hill-country streams. New Zealand Journal of Marine and Freshwater Research 43, 775-802.

HOuinn, J. M., Phillips, N. R. \& Parkyn, S. M. (2007). Factors influencing retention of coarse particulate organic matter in streams. Earth Surface Processes and Landforms 32, 1186-1203.

R Core Team (2019). R: A Language and Environment for Statistical Computing. R Foundation for Statistical Computing, Vienna. https://www.r-project.org/.

\#Rader, R., Bartomeus, I., Tylianakis, J. M. \& Laliberté, E. (2014). The winners and losers of land use intensification: pollinator community disassembly is non-random and alters functional diversity. Diversity and Distributions 20, 908-917.

\#Rahman, M. H., Holmes, A. W. \& Saunders, S. J. (2014). Spatio-temporal variation in soil organic carbon under kiwifruit production systems of New Zealand. Acta Horticulturae 1018, 279-286.

†RAmírez, A. \& Gutiérrez-Fonseca, P. (2014). Functional feeding groups of aquatic insect families in Latin America: a critical analysis and review of existing literature. Revista de biologia tropical 62(Suppl 2), 155-167.

$†$ RaO, E. V. S. P. \& Puttanna, K. (2000). Nitrates, agriculture and environment. Current Science 79, 1163-1168. 
Raudsepp-Hearne, C., Peterson, G. D. \& Bennett, E. M. (2010). Ecosystem service bundles for analyzing tradeoffs in diverse landscapes. Proceedings of the National Academy of Sciences of the United States of America 107, 5242-5247.

$\dagger$ †awat, J., Saxena, J. \& Pankaj, S. (2019). Biochar: a sustainable approach for improving plant growth and soil properties. In Biochar - An Imperative Amendment for Soil and the Environment (eds V. ABrol and P. Sharma), pp. 1-17.IntechOpen, London.

†Reid, D. J., Quinn, J. M. \& Wright-Stow, A. E. (2010). Responses of stream macroinvertebrate communities to progressive forest harvesting: influences of harvest intensity, stream size and riparian buffers. Forest Ecology and Management 260, $1804-1815$.

$\dagger$ Richardson, J. S., Zhang, Y. \& Marczak, L. B. (2010). Resource subsidies across the land-freshwater interface and responses in recipient communities. River Research and Applications 26, 55-66.

$\ddagger$ Riley, R. H., Townsend, C. R., Niyogi, D. K., Arbuckle, C. A. \& PeAcock, K. A. (2003). Headwater stream response to grassland agricultural development in New Zealand. New Zealand Journal of Marine and Freshwater Research 37, 389-403.

Robertson, G. P. \& Swinton, S. M. (2005). Reconciling agricultural productivity and environmental integrity: a grand for agriculture. Frontiers in Ecology and the Environment 3, 38-46.

Rodríguez, J. P., Beard, T. D., Bennett, E. M., Cumming, G. S., Cork, S. J., Agard, J., Dobson, A. P. \& Peterson, G. D. (2006). Trade-offs across space, time, and ecosystem services. Ecology and Society 11, 28.

Rodríguez-Loinaz, G., Alday, J. G. \& Onaindia, M. (2015). Multiple ecosystem services landscape index: a tool for multifunctional landscapes conservation. fournal of Environmental Management 147, 152-163.

$\bowtie$ Rosenberg, M. S., Rothstein, H. R. \& Gurevitch, J. (2013). Effect sizes: conventional choices and calculations. In Handbook of Meta-Analysis in Ecology and Evolution, pp. 61-71.Princeton University Press, Princeton.

$\ddagger$ Ross, D. J., Tate, K. R., Scott, N. A., Wilde, R. H., Rodda, N. J. \& Townsend, J. A. (2002). Afforestation of pastures with Pinus radiata influences soil carbon and nitrogen pools and mineralisation and microbial properties. Australian Journal of Soil Research 40, 1303-1318.

$\ddagger$ Rowe, D. K., Chisnall, B. L., Dean, T. L. \& Richardson, J. (1999). Effects of land use on native fish communities in east coast streams of the North Island of New Zealand. New Zealand Fournal of Marine and Freshwater Research 33, 141-151.

$\bowtie$ RüCKER, G. \& SchWARZER, G. (2015). Ranking treatments in frequentist network meta-analysis works without resampling methods. BMC Medical Research Methodology 15, 58 .

†Rulí́k, M. \& SPÁčIL, R. (2004). Extracellular enzyme activity within hyporheic sediments of a small lowland stream. Soil Biology and Biochemistry 36, 1653-1662.

$†$ Safi, K. A., Hewitt, J. E. \& Talman, S. G. (2007). The effect of high inorganic seston loads on prey selection by the suspension-feeding bivalve, Atrina zelandica. Fournal of Experimental Marine Biology and Ecology 344, 136-148.

SAIDI, N. \& Spray, C. (2018). Ecosystem services bundles: challenges and opportunities for implementation and further research. Environmental Research Letters 13, 113001

SAlanti, G. (2012). Indirect and mixed-treatment comparison, network, or multipletreatments meta-analysis: many names, many benefits, many concerns for the next generation evidence synthesis tool. Research Synthesis Methods 3, 80-97.

Sarkki, S., Ficko, A., Wielgolaski, F. E., Abraham, E. M., BratanovaDoncheva, S., Grunewald, K., Hofgaard, A., Holtmeier, F. K., Kyriazopoulos, A. P., Broll, G., Nijnik, M. \& Sutinen, M. L. (2017). Assessing the resilient provision of ecosystem services by social-ecological systems: introduction and theory. Climate Research 73, 7-15.

†SATtari, S. Z., Bouwman, A. F., Giller, K. E. \& van Ittersum, M. K. (2012). Residual soil phosphorus as the missing piece in the global phosphorus crisis puzzle. Proceedings of the National Academy of Sciences of the United States of America 109, $6348-6353$

¥Scarsbrook, M. R., Quinn, J. M., Halliday, J. \& Morse, R. (2001). Factors controlling litter input dynamics in streams draining pasture, pine, and native forest catchments. New Zealand Fournal of Marine and Freshwater Research 35, 751-762.

† Schipper, L. A. \& LeE, W. G. (2004). Microbial biomass, respiration and diversity in ultramafic soils of West dome, New Zealand. Plant and Soil 262, 151-158.

†SChipper, L. A. \& Sparling, G. P. (2000). Performance of soil condition indicators across taxonomic groups and land uses. Soil Science Society of America Fournal 64, 300-311.

$\bowtie$ Schwarzer, G., Carpenter, J. R. \& Rücker, G. (2015). Network meta-analysis. In Meta-Analysis with r, pp. 187-216.Springer US, Lexington.

Schwarzer, G., RÜcker, G., Krahn, U. \& König, J. (2019). Package 'netmeta' - A comprehensive set of functions providing frequentist methods for network metaanalysis. https://cran.r-project.org/web/packages/netmeta/index.html.

†Scott, N. A., Tate, K. R., Ford-Robertson, J., Giltrap, D. J. \& Smith, C. T. (1999). Soil carbon storage in plantation forests and pastures: land-use change implications. Tellus B 51, 326-335.
\# Selby, M. J. \& Hosking, P. J. (1973). The erodibility of pumice soils of the North Island, New Zealand. Fournal of Hydrology New Zealand 12, 32-56.

†Shahid, M., Shamshad, S., RafiQ, M., Khalid, S., Bibi, I., Niazi, N. K., Dumat, C. \& Rashid, M. I. (2017). Chromium speciation, bioavailability, uptake, toxicity and detoxification in soil-plant system: a review. Chemosphere 178, 513-533.

†Sharpley, A. \& Beegle, D. (2001). Managing phosphorus for agriculture and the environment. https://extension.psu.edu/programs/nutrient-management/ educational/soil-fertility/managing-phosphorus-for-agriculture-and-theenvironment .

\$Shearer, K. A. \& Young, R. G. (2011). Influences of geology and land use on macroinvertebrate communities across the Motueka River catchment, New Zealand. New Zealand Fournal of Marine and Freshwater Research 45, 437-454.

†Shukla, P. N., Pandey, K. D. \& Mishra, V. K. (2013). Environmental determinants of soil methane oxidation and Methanotrophs. Critical Reviews in Environmental Science and Technology 43, 1945-2011.

‡Simon, K. S., Niyogi, D. K., Frew, R. D. \& Townsend, C. R. (2007). Nitrogen dynamics in grassland streams along a gradient of agricultural development. Limnology and Oceanography 52, 1246-1257.

‡Singh, B. K., Tate, K. R., Kolipaka, G., Hedley, C. B., Macdonald, C. A., Millard, P. \& Murrell, J. C. (2007). Effect of afforestation and reforestation of pastures on the activity and population dynamics of methanotrophic bacteria. Applied and Environmental Microbiology 73, 5153-5161.

‡Singh, B. K., Tate, K. R., Ross, D. J., Singh, J., Dando, J., Thomas, N., Millakd, P. \& Murrell, J. C. (2009). Soil methane oxidation and methanotroph responses to afforestation of pastures with Pinus radiata stands. Soil Biology and Biochemistry 41, 2196-2205.

$\dagger$ Soll Management India (2019). Soil and plant growth. http://www. soilmanagementindia.com/soil-condition/soil-and-plant-growth/2905 .

Spake, R., Lasseur, R., Crouzat, E., Bullock, J. M., Lavorel, S., Parks, K. E., Schaafsma, M., Bennett, E. M., Maes, J., Mulligan, M., Mouchet, M., Peterson, G. D., Schulp, C. J. E., Thuiller, W., Turner, M. G., et al. (2017). Unpacking ecosystem service bundles: towards predictive mapping of synergies and trade-offs between ecosystem services. Global Environmental Change 47, $37-50$.

†Sparling, G., Chibnall, E., Pronger, J., Rutledge, S., Wall, A., Campbell, D. \& Schipper, L. (2016). Estimates of annual leaching losses of dissolved organic carbon from pastures on Allophanic soils grazed by dairy cattle, Waikato, New Zealand. New Zealand Fournal of Agricultural Research 59, 32-49.

\$SPARLing, G. P. \& Schipper, L. A. (2002). Ecological risk assessment: soil quality at a national scale in New Zealand. Fournal of Environmental Quality; Madison 31, 1848 1857.

†SPARling, G. P. \& Schipper, L. A. (2004). Soil quality monitoring in New Zealand: trends and issues arising from a broad-scale survey. Agriculture, Ecosystems and Environment 104, 545-552.

¥Sparling, G. P. \& SEARLE, P. L. (1993). Dimethyl sulphoxide reduction as a sensitive indicator of microbial activity in soil: the relationship with microbial biomass and mineralization of nitrogen and Sulphur. Soil Biology and Biochemistry 25, 251-256.

¥SPARLING, G. P. (1992). Ratio of microbial biomass carbon to soil organic carbon as a sensitive indicator of changes in soil organic matter. Soil Research 30, 195-207.

‡Sparling, G. P., Lewis, R. W., Schipper, L. A., Mudge, P. L. \& Balks, M. (2014). Changes in soil total $\mathrm{C}$ and $\mathrm{N}$ contents at three chronosequences after conversion from plantation pine forest to dairy pasture on a New Zealand pumice soil. Soil Research 52, 38-45.

\#Sparling, G. P., Shepherd, T. G. \& Schipper, L. A. (2000). Topsoil characteristics of three contrasting New Zealand soils under four long-term land uses. New Zealand fournal of Agricultural Research 43, 569-583.

$\dagger$ Spectrum Analytic (2019). Calcium in the soil. https://www.spectrumanalytic. com/support/library/ff/Ca_Basics.htm .

\#†Stankiewicz, M., Jowett, G. H., Roberts, M. G., Heath, D. D., Cowan, P., Clark, J. M., Jowett, J. \& Charleston, W. A. G. (1996). Internal and external parasites of possums (Trichosurus vulpecula) from forest and farmland, Wanganui, New Zealand. New Zealand fournal of Zoology 23, 345-353.

†Stark, J. D. \& Maxted, J. R. (2007a). A biotic index for New Zealand's softbottomed streams. New Zealand Journal of Marine and Freshwater Research 41, 43-61.

$\dagger$ †tark, J. D. \& Maxted, J. R. (2007b). A User Guide for the Macroinvertebrate Community Index Prepared for the Ministry for the Environment - Cawthron Report No.1166. Cawthron Institute, Nelson.

Steffen, W., Richardson, K., Rockstrom, J., Cornell, S. E., Fetzer, I., Bennett, E. M., Biggs, R., Carpenter, S. R., de Vries, W., de Wit, C. A., Folke, C., Gerten, D., Heinke, J., Mace, G. M., Persson, L. M., et al. (2015). Planetary boundaries: guiding human development on a changing planet. Science $347,1259855$.

\#STEvenson, B. A. (2004). Changes in phosphorus availability and nutrient status of indigenous forest fragments in pastoral New Zealand Hill country. Plant and Soil 262, 317-325. 
\$STORey, R. G. \& Cowley, D. R. (1997). Recovery of three New Zealand rural stream as they pass through native forest remnants. Hydrobiologia 353, 63-76.

†STream Bryophyte Group (1999). Roles of bryophytes in stream ecosystems. Fournal of the North American Benthological Society 18, 151-184.

\#†Sullivan, J. J., Timmins, S. M. \& Williams, P. A. (2005). Movement of exotic plants into costal native forests from gardens in northern New Zealand. New Zealand Journal of Ecology 1, 1-10.

Sutherland, I. J., Gergel, S. E. \& Bennett, E. M. (2016). Seeing the forest for its multiple ecosystem services: indicators for cultural services in heterogeneous forests. Ecological Indicators 71, 123-133.

$\dagger$ TAHOUN, S.A. (1962). The effect of chelates on phosphorus availability and mobility. Master's thesis, Utah State University.

\$Tate, K. R., Ross, D. J., Saggar, S., Hedley, C. B., Dando, J., Singh, B. K. \& LAmbie, S. M. (2007). Methane uptake in soils from Pinus radiata plantations, a reverting shrubland and adjacent pastures: effects of land-use change, and soil texture, water and mineral nitrogen. Soil Biology and Biochemistry 39, 1437-1449.

\$Tate, K. R., Walcroft, A. S. \& Pratt, C. (2012). Varying atmospheric methane concentrations affect soil methane oxidation rates and methanotroph populations in pasture, an adjacent pine forest, and a landfill. Soil Biology and Biochemistry 52, 75-81.

$\bowtie$ TAYLOR, L. R. (1961). Aggregation, variance and the mean. Nature 189, 732-735.

TEEB (2010). The Economics of Ecosystems and Biodiversity: Mainstreaming the Economics of Nature: $A$ Synthesis of the Approach, Conclusions and Recommendations of TEEB, p. 39. Malta: Progress Press. http://www.teebweb.org/wp-content/uploads/Study\%20and\%20Reports/ Reports/Synthesis\%20report/TEEB\%20Synthesis\%20Report\%202010.pdf.

$†$ TETI, P. (2003). Shade and stream temperature. Watershed Management Bulletin 7, 1-5.

\$Thompson, R. M. \& Townsend, C. R. (2003). Impacts on stream food webs of native and exotic Forest: an intercontinental comparison. Ecology 84, 145-161.

\#Thompson, R. M. \& Townsend, C. R. (2004a). Land-use influences on New Zealand stream communities: effects on species composition, functional organisation, and food-web structure. New Zealand Fournal of Marine and Freshwater Research 38, 595-608.

\$Thompson, R. M. \& Townsend, C. R. (2004b). Impacts of riparian afforestation on stream biofilms: an exotic forest-native grassland comparison. New Zealand Fournal of Marine and Freshwater Research 38, 895-902.

$\bowtie$ Thompson, S., Grüner, I. \& GAPARE, N. (2003). Illustrated Guide to Target Classes of the New Zealand Land Cover Database Version 2. New Zealand Ministry for the Environment, Wellington.

¥Townsend, C. R., Downes, B. J., Peacock, K. A. \& Arbuckle, C. J. (2004). Scale and the detection of land-use effects on morphology, vegetation and macroinvertebrate communities of grassland streams. Freshwater Biology 49, 448-462.

†Townsend, C. R., Thompson, R. M., McIntosh, A. R., Kilroy, C., Edwards, E. \& Scarsbrook, M. R. (1998). Disturbance, resource supply, and food web architecture in streams. Ecology Letters 1, 200-209.

Tscharntke, T., Klein, A. M., Kruess, A., Steffan-Dewenter, I. \& Thies, C. (2005). Landscape perspectives on agricultural intensification and biodiversity ecosystem service management. Ecology Letters 8, 857-874

Turner, B. L., Lambin, E. F. \& ReenberG, A. (2008). The emergence of land change science for global environmental change and sustainability. Proceedings of the National Academy of Sciences of the United States of America 105, 20666-20671.

$\dagger$ United States Department of Agriculture Natural Resources Conservation Service (2014). Potentially mineralisable nitrogen - soil quality indicators. https://www.nrcs.usda.gov/wps/PA_NRCSConsumption/download? cid=stelprdb $1243371 \&$ ext=pdf .

†United States Environmental Protection Agency (2015). Reduction in median load of total Kjeldahl Nitrogen (TKN) due to tree cover. https:// enviroatlas.epa.gov/enviroatlas/datafactsheets/pdf/esc/ reductioninmedianloadoftotalkjeldahlnitrogentknduetotreecover.pdf

†United States Environmental Protection Agency (2019). National aquatic resource surveys - indicators: streambed sediments. https://www.epa.gov/nationalaquatic-resource-surveys/indicators-streambed-sediments .

†United States Geological Survey (2019a) Uses of streamflow information. https://www.usgs.gov/special-topic/water-science-school/science/usesstreamflow-information?Qt-science_center_objects=0\#qt-scienc_center_objects .

$\dagger$ United States Geological Survey (2019b) Surface runoff and the water cycle. https://water.usgs.gov/edu/watercyclerunoff.html .

Vallet, A., Locatelli, B., Levrel, H., Wunder, S., Seppelt, R., Scholes, R. J. \& Oszwald, J. (2018). Relationships between ecosystem services: comparing methods for assessing tradeoffs and synergies. Ecological Economics 150, 96-106.

†Verheyen, D., van Gaelen, N., Ronchi, B., Batelaan, O., Struyf, E., Govers, G., Merckx, R. \& Diels, J. (2015). Dissolved phosphorus transport from soil to surface water in catchments with different land use. Ambio 44, 228-240.

†Vernier Software and Technology (2019). Ammonium nitrogen. https:// www.vernier.com/experiment/wqv-10_ammonium-nitrogen/.

Villamagna, A. M., Angermeier, P. L. \& Bennett, E. M. (2013). Capacity, pressure, demand, and flow: a conceptual framework for analyzing ecosystem service provision and delivery. Ecological Complexity 15, 114-121.
\$Vink, C. J., Teulon, D. A. J., Mclachlan, A. R. G. \& Stufkens, M. A. W. (2004). Spiders (Araneae) and harvestmen (Opiliones) in arable crops and grasses in Canterbury, New Zealand. New Zealand Fournal of Zoology 31, 149-159.

†Wakelin, S. A., Macdonald, L. M., O’Callaghan, M., Forrester, S. T. \& Condron, L. M. (2014). Soil functional resistance and stability are linked to different ecosystem properties. Austral Ecology 39, 522-531.

$\bowtie$ Wallace, B.C., Small, K., Brodley, C.E., Lau, J. \& Trikalinos, T.A. (2012) Deploying an interactive machine learning system in an evidence-based practice center. Proceedings of the 2nd ACM SIGHIT symposium on International health informatics - IHI '12, 819.

WAllace, K. J. (2007). Classification of ecosystem services: problems and solutions. Biological Conservation 139, 235-246.

†WAlworth, J. (2013). Nitrogen in soil and the environment. https://extension. arizona.edu/sites/extension.arizona.edu/files/pubs/az1591.pdf .

$\bowtie$ WAN, X., WANG, W., LiU, J. \& Tong, T. (2014). Estimating the sample mean and standard deviation from the sample size, median, range and/or interquartile range. BMC Medical Research Methodology 14, 135.

†WARdle, D. A. \& GHani, A. (1995). A critique of the microbial metabolic quotient (qCO2). As a bioindicator of disturbance and ecosystem development. Soil Biology and Biochemistry 27, 1601-1610.

¥Waterhouse, B. R., Adair, K. L., Boyer, S. \& Wratten, S. D. (2014). Advanced mine restoration protocols facilitate early recovery of soil microbial biomass, activity and functional diversity. Basic and Applied Ecology 15, 599-606.

$\dagger$ Watershed Science Institute (2019). The EPT Index - Watershed Condition Series Technical Note 3. Watershed Science Institute, San Diego.

\$WATts, L. F. \& Hawke, R. M. (2003). The effects of urbanisation on hydrologic response: a study of two coastal catchments. Fournal of Hydrology New Zealand 42, 125-143.

+White, J. D., Coops, N. C. \& Scott, N. A. (2000). Estimates of New Zealand forest and scrub biomass from the 3-PG model. Ecological Modelling 131, 175-190.

\$Whitmore, N., Alexander, D., Huryn, A. D., Arbuckle, C. \& Jansma, F. (2000). Ecology and Distribution of the Freshwater Crayfish Paranephrops zealandicus in Otago Implications for Conservation. - Science for Conservation 148, p. 42. Department of Conservation, Wellington.

‡Wilcock, R. J., Nagels, J. W., McBride, G. B., Collier, K. J., Wilson, B. T. \& Huser, B. A. (1998). Characterisation of lowland streams using a single-station diurnal curve analysis model with continuous monitoring data for dissolved oxygen and temperature. New Zealand Fournal of Marine and Freshwater Research 32, 67-79.

\$Wilson, D. J., Norbury, G. \& Walker, S. (2014). How does woody succession affect population densities of passerine birds in New Zealand drylands? New Zealand Fournal of Ecology 38, 257-267.

†Winter, T. C., Harvey, J. W., Franke, O. L. \& Alley, W. (1998). Natural process of ground-water and surface-water interaction. In Groundwater and Surface Water a Single Resource - U.S. Geological Survey Circular 1139, pp. 2-54.U.S. Geological Survey, Denver.

*Wolinska, A. \& STEPniEwsk, Z. (2012). Dehydrogenase activity in the soil environment. In Dehydrogenases (ed. R. A. CanuTo), pp. 183-210.InTech Open, London. $\dagger$ World Health Organization (2005). Nickel in Drinking-Water: Background Document for Development of WHO Guidelines for Drinking-Water Quality. World Health Organization, Geneva.

†Wuana, R. A. \& OKIEImen, F. E. (2011). Heavy metals in contaminated soils: a review of sources, chemistry, risks and best available strategies for remediation. International Scholarly Research Notices 2011, 1-20.

†YAmakura, T. \& SAhunalu, P. (1990). Soil carbon/nitrogen ratio as a site quality index for some south-east Asian forests. Fournal of Tropical Ecology 6, 371-377.

\$Yeates, G. W., Hawke, M. F. \& Rijkse, W. C. (2000). Changes soil fauna and soil conditions under Pinus radiata agroforestry regimes during a 25-year tree rotation. Biology and Fertility of Soils 31, 391-406.

\$Yeates, G. W., Saggar, S. \& Daly, B. K. (1997). Soil microbial C, N, and P, and microfaunal populations under Pinus radiata and grazed pasture land-use systems. Pedobiologia 41, 549-565.

†YUNG, R. G. \& Huryn, A. D. (1996). Interannual variation in discharge controls ecosystem metabolism along a grassland river continuum. Canadian fournal of Fisheries and Aquatic Sciences 53, 2199-2211.

†Young, R. G., Quarterman, A. J., Eyles, R. F., Smith, R. A. \& Bowden, W. B. (2005). Water quality and thermal regime of the Motueka River: influences of land cover, geology and position in the catchment. New Zealand fournal of Marine and Freshwater Research 39, 803-825.

\$Zheng, T., Hamel, K. L. \& Buddle, B. M. (2010a). A serological survey of the prevalence of antibodies against enteroviruses in brushtail possums (Tichosurus vulpecula) in New Zealand: enteroviruses have a limited distribution in brushtail possums. New Zealand Veterinary fournal 58, 23-28.

†Zheng, T., Hamel, K. L. \& Buddle, B. M. (2010b). A serological survey of the prevalence of antibodies against enteroviruses in brushtail possums (Tichosurus vulpecula) in New Zealand: enteroviruses have a limited distribution in brushtail possums. New Zealand Veterinary Foumal 58, 23-28.

$†$ Zheng, Z.-C., He, S.-Q. \& WU, F.-Q. (2014). Changes of soil surface roughness under water erosion process. Hydrological Processes 28, 3919-3929. 


\section{Supporting information}

Additional supporting information may be found online in the Supporting Information section at the end of the article. Supplementary Methods S1. Detailed data collection and processing methods.

Supplementary Methods S2. Full search phrase for pilot and formal searches.

Supplementary Methods S3. Decision tree with selection criteria used in the full-text assessment of publications with relevant abstracts for our review.

Supplementary Methods S4. Conversion of confidence intervals to variance and imputation of missing values.

Supplementary Methods S5. Scree plots and land cover classification for multivariate analyses.

Supplementary Results S1. Overview of research effort for New Zealand.

Supplementary Results S2. Evidence base and network meta-analysis for individual ESs.
Supplementary Results S3. Summary of log response ratios per land cover and ecosystem service combination.

Supplementary Results S4. Detailed results from PERMANOVA analyses.

Supplementary Results S5. Data analysis with allocation of a single ES to each indicator.

Supplementary Data Set S1. Overview of Ecosystem Services (ESs).

Supplementary Data Set S2. Overview of land cover classes as defined in New Zealand's Land Cover Database (LCDB) (Thompson et al., 2003).

Supplementary Data Set S3. Reference list for the studies included in our meta-analysis.

Supplementary Data Set S4. Quantitative indicators used to quantify supply of each ecosystem service.

Supplementary Data Set S5. Final log response ratios on ecosystem service supply for pairwise comparison of land covers in each study used in our analysis.

(Received 16 December 2019; revised 2 May 2021; accepted 6 May 2021; published online 24 May 2021) 